\title{
Environmental assessment of thermo-chemical processes for bio-ethylene production in comparison with bio- chemical and fossil-based ethylene
} DOI:

10.1016/j.jclepro.2018.08.147

\section{Document Version \\ Accepted author manuscript}

Link to publication record in Manchester Research Explorer

Citation for published version (APA):

Alonso-fariñas, B., Gallego-schmid, A., Haro, P., \& Azapagic, A. (2018). Environmental assessment of thermochemical processes for bio-ethylene production in comparison with bio-chemical and fossil-based ethylene. Journal of Cleaner Production, 202, 817-829. https://doi.org/10.1016/j.jclepro.2018.08.147

\section{Published in:}

Journal of Cleaner Production

\section{Citing this paper}

Please note that where the full-text provided on Manchester Research Explorer is the Author Accepted Manuscript or Proof version this may differ from the final Published version. If citing, it is advised that you check and use the publisher's definitive version.

\section{General rights}

Copyright and moral rights for the publications made accessible in the Research Explorer are retained by the authors and/or other copyright owners and it is a condition of accessing publications that users recognise and abide by the legal requirements associated with these rights.

\section{Takedown policy}

If you believe that this document breaches copyright please refer to the University of Manchester's Takedown Procedures [http://man.ac.uk/04Y6Bo] or contact uml.scholarlycommunications@manchester.ac.uk providing relevant details, so we can investigate your claim.

\section{OPEN ACCESS}




\title{
Environmental assessment of thermo-chemical processes for bio-ethylene production in comparison with bio-chemical and fossil-based ethylene
}

\author{
Bernabé Alonso-Fariñas ${ }^{\mathrm{a}^{*}}$, Alejandro Gallego-Schmid ${ }^{\mathrm{b}^{*}}$, Pedro Haro $^{\mathrm{a}}$, Adisa Azapagic ${ }^{\mathrm{b}}$ \\ a Departamento de Ingeniería Química y Ambiental, Escuela Técnica Superior de Ingeniería, \\ Universidad de Sevilla, Camino de los Descubrimientos s/n. 41092 Seville, Spain. \\ ${ }^{\mathrm{b}}$ Sustainable Industrial Systems, School of Chemical Engineering and Analytical Science, The \\ University of Manchester, The Mill, Sackville Street, Manchester M13 9PL, UK
}

*Corresponding authors: bernabeaf@us.es; alejandro.gallegoschmid@manchester.ac.uk

\begin{abstract}
The use of biomass for production of chemicals is gaining interest because of its potential to contribute towards a reduction in greenhouse gas emissions and other environmental benefits linked to the substitution of fossil resources. But, conversely to biofuels, studies focusing on environmental impacts of biomass-derived chemicals are scarce. This paper uses life cycle assessment to evaluate the environmental sustainability of bio-ethylene from poplar produced by the following three thermo-chemical routes: direct and indirect dehydration of ethanol and production of olefins via dimethyl ether. The indirect route is the best option for most impact categories for all three allocation methods considered: system expansion, economic and energy basis. However, the dimethyl ether-to-olefins route has the lowest global warming potential. In comparison to ethylene produced bio-chemically from sugar beet, the thermo-chemical indirect route has lower impacts for all categories except human, terrestrial and freshwater toxicities. All three thermo-chemical alternatives show a significant reduction in global warming potential (up to $105 \%$ in the case of dimethyl ether-to-olefins) and depletion of fossil fuels when compared to conventional ethylene production from fossil fuels. However, the results also suggest that bioethylene produced by any of the three thermo-chemical routes would lead to a significant increase in most other impact categories relative to fossil fuels. Therefore, while trying to reduce greenhouse gas emissions, the overall environmental sustainability of bio-ethylene suffers from the increase in other environmental impacts.
\end{abstract}

Keywords: Bio-chemical production; climate change; environmental sustainability; ethylene; life cycle assessment.

\section{Introduction}

The European chemicals industry is committed to a gradual increase in the utilization of renewable feedstocks, with the objective of producing 25\% of biomass-derived chemicals in 2030 (DSBC, 2012). Biomass-derived chemicals act as a storage of biogenic carbon (Haro et al., 2014) and could potentially have negative net greenhouse gas emissions (The Royal Society, 2016). This makes them an appealing target for reducing the impact on climate change from the chemicals industry. Among the candidates for producing bio-chemicals, ethylene stands out as the largest chemical commodity with the global demand of 150 million tonnes in 2016 (Mitsubishi Chemical, 2017). Ethylene is currently largely produced by steam cracking using different hydrocarbon feedstocks (ethane, propane, naphtha and gas oils), although the use of ethane is being favoured, especially in Europe (Ethylene Profile, 2015).

Even though bio-ethylene production is still far from playing an important role in the near future, it can complement production of fossil-based olefins (Amghizar et al., 2017; Braskem Company, 2017). Compared to other biomass-derived chemicals, the production of bio-ethylene has an advantage that it can be introduced directly into existing value chains, infrastructure and markets (Arvidsson, 2016). Ethylene can be produced from biomass following two different pathways: bio- 
chemical and thermo-chemical. In the former, ethanol produced from the fermentation of sugars is dehydrated into ethylene. The Brazilian company Braskem is already producing $200,000 \mathrm{t} / \mathrm{y}$ of polymer-grade bio-ethylene using sugarcane bio-ethanol as an intermediate (Braskem Company, 2017).

In the thermo-chemical pathway, lignocellulosic biomass is converted into ethylene prior to thermal treatment (pyrolysis and/or gasification) and further chemical conversion of produced syngas into ethylene. There are two alternatives for the chemical conversion, either the production of methanol/dimethyl ether (DME) or ethanol as chemical intermediates. In the case of methanol/DME, a methanol-to-olefins reactor is used. For ethanol, the same dehydration process as in the bio-chemical pathway is utilized. Several studies have evaluated techno-economic feasibility of ethylene production via the bio-chemical route, including Kamzon et al. (2016), Becerra et al. (2017) and Nitzsche et al. (2016). Equivalent studies of thermo-chemical pathways have also been carried out (Haro et al., 2013; McKechnie et al., 2015; Sharifzadeh et al., 2015). In this study, we focus on the thermo-chemical route to evaluate the environmental sustainability of producing bio-ethylene from biomass. The results are compared with bio-chemical ethylene produced by dehydration of first-generation bio-ethanol and with ethylene obtained by steam cracking of fossil resources. The following three main alternative pathways are considered: direct ethanol dehydration, indirect ethanol dehydration and DME-to-olefins. Therefore, the scope of the work covers the most promising alternatives for bio-ethylene production via thermo-chemical conversion (Haro et al., 2013).

In contrast to biofuels, there are scarce examples of life cycle assessment (LCA) studies of biomass-derived chemicals. Most existing studies are focused on specialty chemicals produced via the bio-chemical pathway (e.g. Fiorentino et al., 2017) and only a few on chemical commodities like ethylene (e.g. Cheali et al., 2015). Studies of life cycle impacts of ethylene production using the thermo-chemical pathway are rare and the number of impacts considered is limited. For example, Karka et al. (2017) considered only three categories: cumulative energy demand, global warming potential and water consumption. A couple of other studies discussed the key environmental issues in the production of bio-ethylene focusing on second-generation ethanol (Belboom and Leonard, 2016; Liptow et al., 2013). First-generation bio-chemical ethanol was studied by Ghanta et al. (2014) who considered corn as a feedstock in a US context while Tsiropoulos et al. (2015) evaluated the use of sugarcane in Brazil and India. Sugarcane from Brazil was also considered by Kikuchi et al. (2017) for the production of ethanol in Japan, alongside the use of domestic sugarcane-molasses. Other studies assessed the economic and environmental implications of using bio-ethanol for ethylene production instead of utilizing it as a transportation fuel (McKechnie et al., 2015; Posen et al., 2015). Finally, Horváth et al. (2017) analysed the carbon efficiency of the conversion of bio-ethanol into different chemicals, including ethylene.

Therefore, there is a lack of comprehensive studies of environmental impacts of thermo-chemical production of ethylene from biomass. This study aims to fill this knowledge gap. The results are compared to the impacts from ethylene produced by bio-chemical conversion as well as with ethylene produced from fossil feedstocks to provide a comprehensive multi-criteria analysis of the environmental performance of bio-ethylene. As far as we are aware, this is the first study of its kind internationally.

\section{Methodology}

The study involves a comparative attributional LCA, based on the guidelines of the ISO 14040/44 standards (2006a, 2006b). The goal and scope of the study are described next, followed by the inventory data and an overview of the impact assessment method used in the study.

\subsection{Goal and scope}

The main goal of the study is to estimate and compare life cycle environmental impacts of the three alternative methods for producing bio-ethylene from biomass via thermo-chemical conversion: direct ethanol dehydration (Case 1); indirect ethanol dehydration (Case 2); and DME to olefins 
(Case 3). A further goal is to compare these thermo-chemical routes with ethylene produced from first-generation ethanol via the bio-chemical route and with ethylene from fossil-based resources.

As indicated in Figure 1, the scope of the study is from 'cradle to gate', with two main stages considered: biomass supply (cultivation, collection and transportation to the processing plant); and production of bio-ethylene and its co-products. The use of bio-ethylene and the co-products, as well as their distribution, are excluded from the system boundaries. The construction and decommissioning of the production plant are also excluded as the impacts of infrastructure per unit of product are negligible over the (long) lifespan of industrial plants (Reyes Valle et al., 2015).

The functional unit is defined as the production of 1 tonne of ethylene.

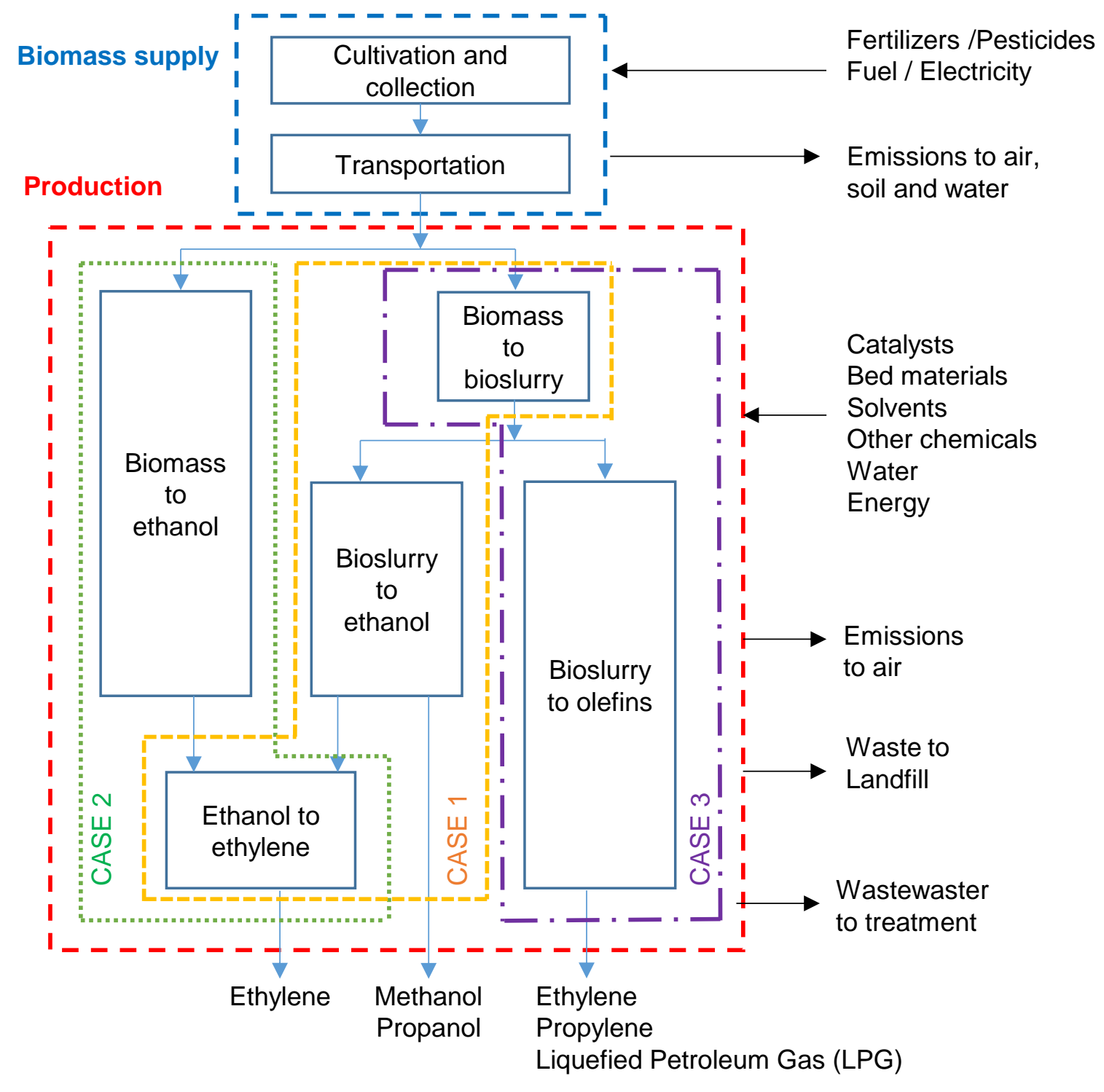

Figure 1 Systems boundaries considered for the production of bio-ethylene via the thermochemical route.

(Case 1: direct ethanol dehydration; Case 2: indirect ethanol dehydration; Case 3: dimethyl ether to ethylene.)

\subsection{System description}

The plant size chosen is equivalent to $500 \mathrm{MWth}$ in terms of the energy content of the feedstock processed, based on the higher heating value (HHV). This plant size is typically considered in studies of biomass-to-liquids (BTL) plants (Villanueva et al., 2011). The type of biomass processed in the plant is the same for each of the three cases considered. However, the amount of biomass required per tonne of ethylene produced and the output of the co-products vary depending of the 
production route due to the different efficiency and selectivity of the three routes. The feedstock is poplar as detailed in the next section.

\subsubsection{Feedstock supply}

Poplar is selected as the feedstock, which has recently attracted significant interest as an energy crop (Guo, 2014). The production plant is assumed to be based in the Duero Valley (Castilla $y$ León, Spain) as there is extensive cultivation of poplar there due to favourable climatic conditions. For these reasons, land use change is not considered.

The life cycle of a poplar crop spans 16 years. In the first year, land preparation and the planting of cuttings take place. This is followed by three tree-growing cycles of five years each (Gasol et al., 2009), with the trees being cut to the ground after each cycle. At the end of the third cycle, the trunks are treated with insecticide to remove the roots and, after three months, new cuttings are planted. The average production of biomass is $216 \mathrm{t} / \mathrm{ha}$ on a dry basis for the three cycles as a whole. Further description of the feedstock supply can be found in Reyes Valle et al. (2015).

\subsubsection{Case 1: Direct ethanol dehydration}

This process involves three main steps:

i) bioslurry production from biomass (Figure 2);

ii) production of ethanol from bioslurry by direct route through gasification and catalytic conversion of syngas (Figure 3); and

iii) production of ethylene by ethanol dehydration (Figure 4), based on a commercial technology (Chematur Engineering AB, 2017).

A detailed description of this route is given in the Supporting Information (SI).

\subsubsection{Case 2: Indirect ethanol dehydration}

In this case, there are two main stages:

i) production of ethanol from biomass by indirect route; and

ii) production of ethylene by ethanol dehydration.

i) The process for producing ethanol is detailed in Figure 5 (Haro et al., 2012). It follows the following sequence: first, a fraction of the syngas is used for methanol synthesis; the methanol is then dehydrated to DME and water; and finally, DME and the rest of the syngas are reacted to produce ethanol via methyl acetate. Methanol is also produced in this last step. For further details, see the SI.

ii) The production of ethylene follows the same process as in Figure 4.

\subsubsection{Case 3: DME to olefins}

Case 3 comprises two main steps:

i) bioslurry production; and

ii) production of olefins.

The bioslurry and the olefins are produced in the processes outlined in Figure 2 and Figure 6 (Haro et al., 2013), respectively. A detailed description is provided in the SI. 


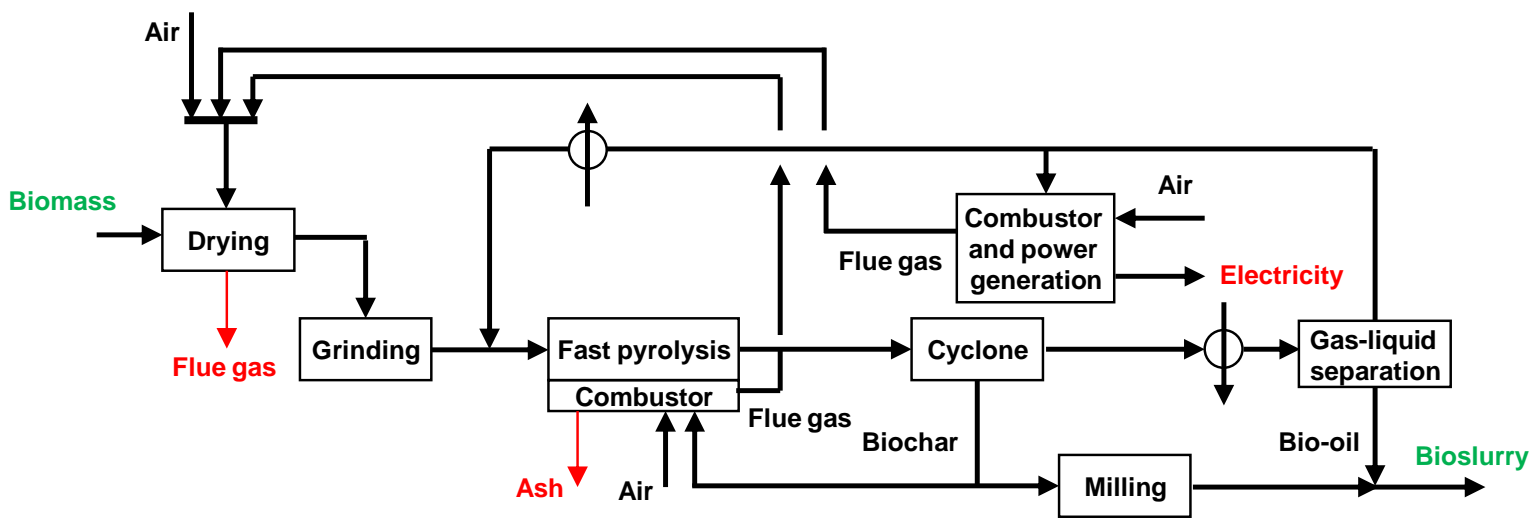

Figure 2 Bioslurry production used in the direct ethanol dehydration route (Case 1) and in the DME-to-olefins route (Case 3).

(Adapted from Villanueva et al. (2011). The green colour (in the online version of the paper) refers to the main input and output from the process. The red colour (online version) signifies the outputs from the process, including co-products.)

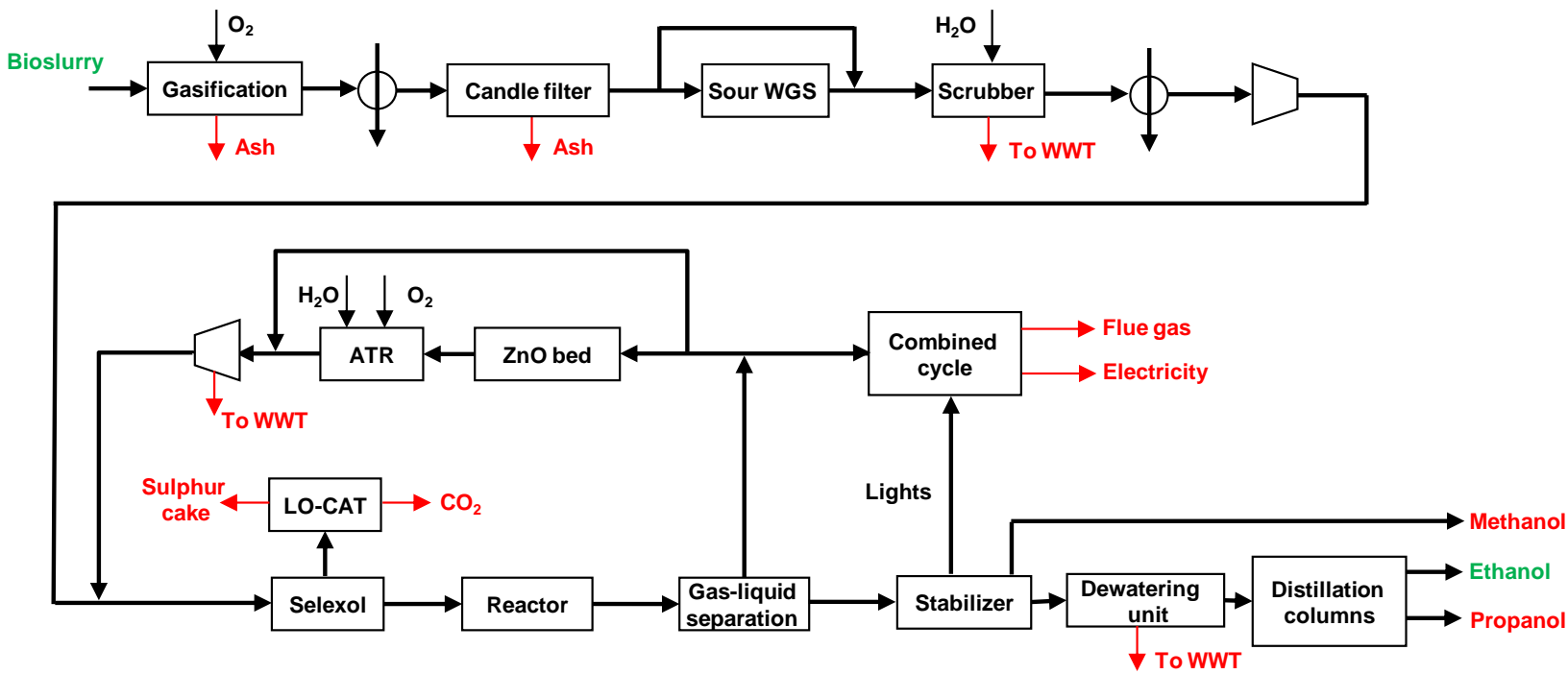

Figure 3 Ethanol production via the direct route (Case 1).

(Adapted from Villanueva et al. (2011). WGS: water-gas shift; WWT: wastewater treatment; ATR: autothermal reformer; LO-CAT: liquid-phase oxidation catalytic unit. The green colour (in the online version of the paper) refers to the main input and output from the process. The red colour (online version) signifies the outputs from the process, including coproducts.)
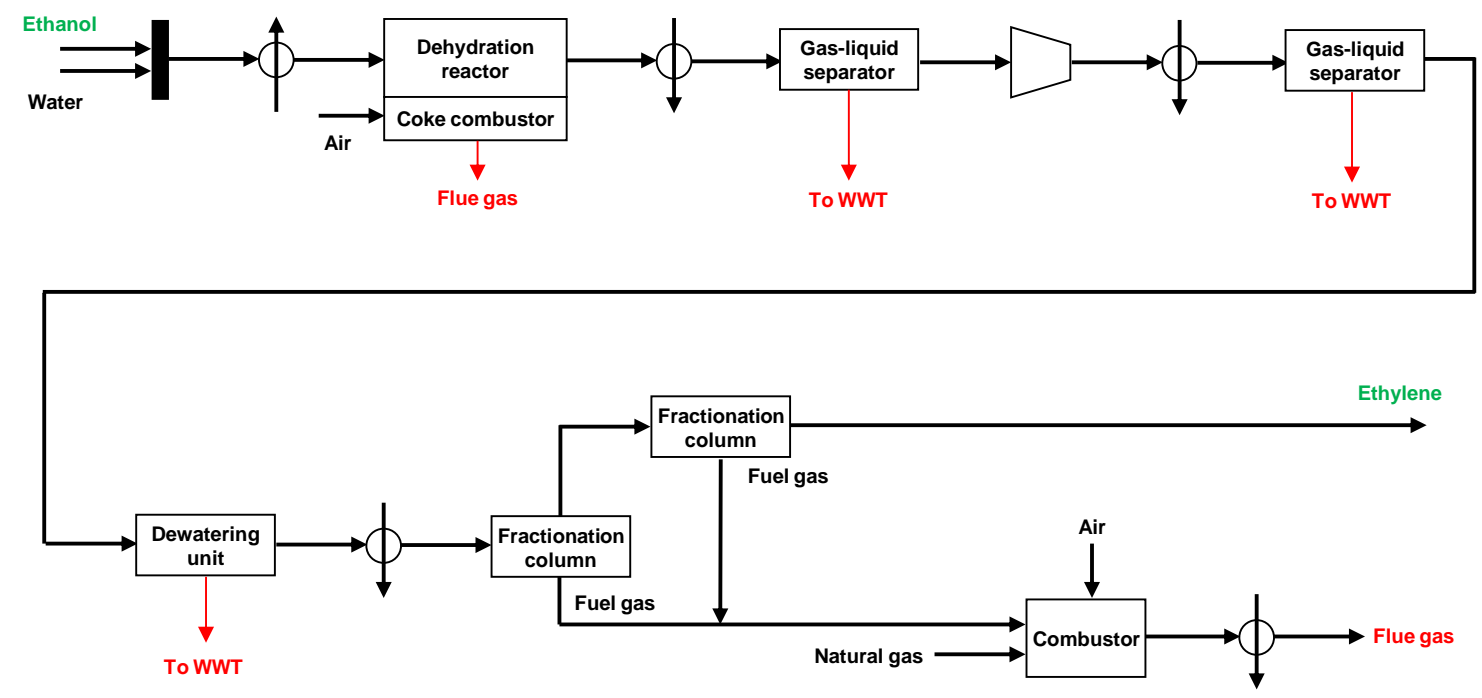

Figure 4 Ethylene production by dehydration of ethanol.

(Adapted from Villanueva et al. (2011). WWT: wastewater treatment. The green colour (in the online version of the paper) refers to the main input and output from the process. The red colour (online version) signifies the outputs from the process, including co-products.) 

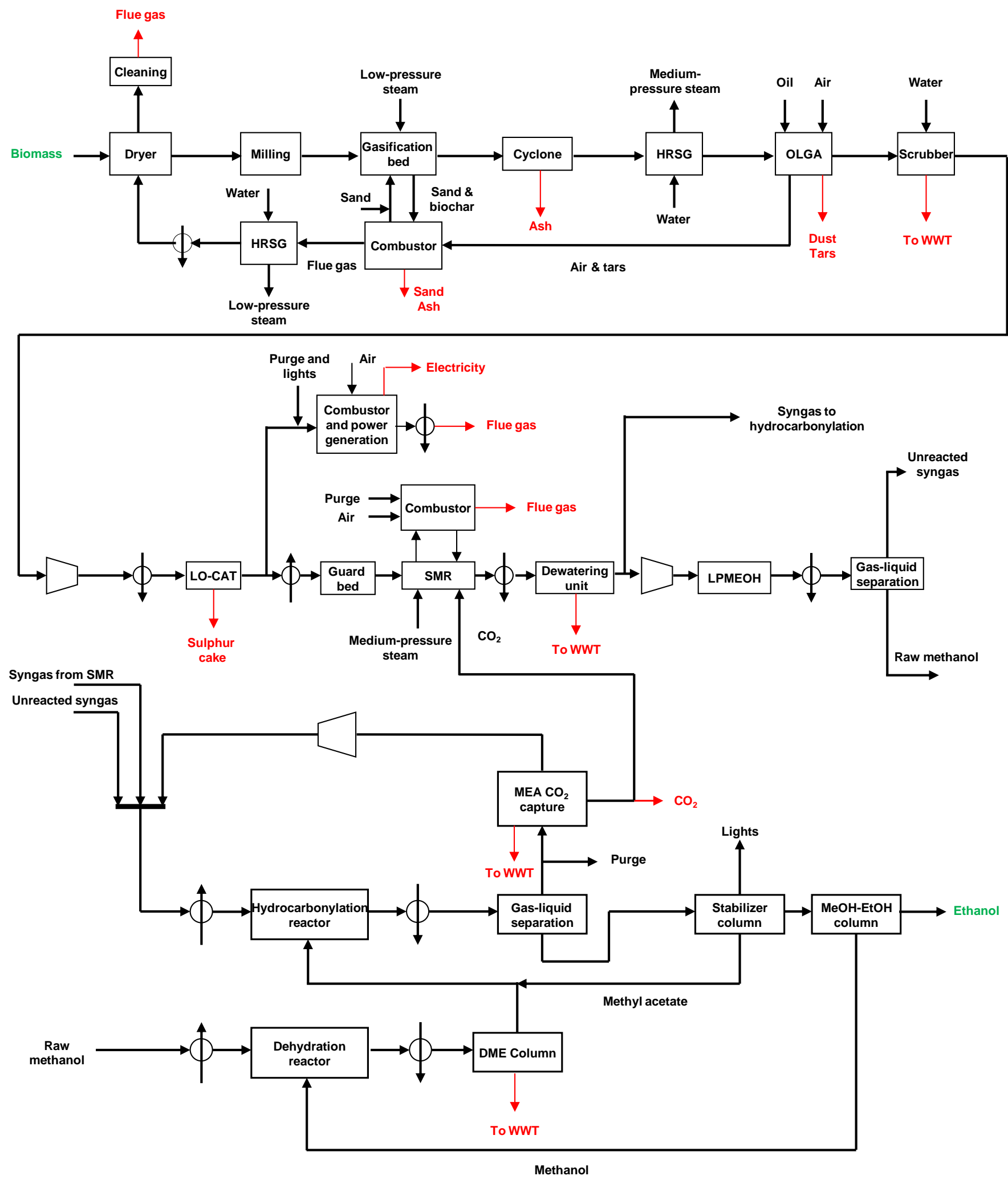

Figure 5 Ethanol production via the indirect route (Case 2).

(Adapted from Haro et al. (2012). HRSG: heat recovery steam generator; LPMEOH: liquid-phase methanol; LO-CAT: liquid-phase oxidation catalytic unit; SMR: steam methane reformer; MEA: monoethanolamine; DME: dimethyl ether. The green colour (in the online version of the paper) refers to the main input and output from the process. The red colour (online version) signifies the outputs from the process, including co-products.) 

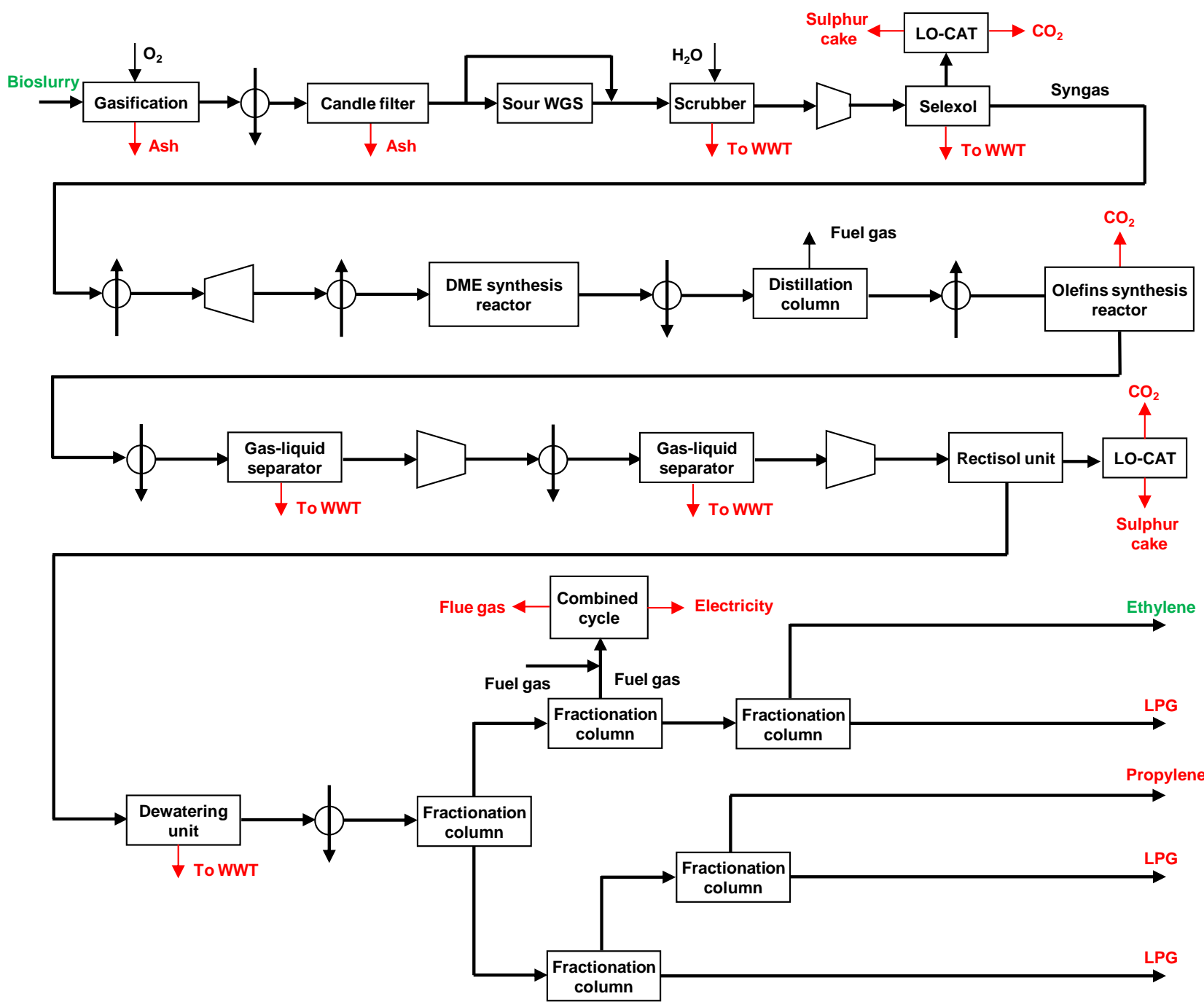

\section{Figure 6 Production of olefins via dimethyl ether (Case 3).}

(Adapted from Haro et al. (2012). WGS: water-gas shift; WWT: wastewater treatment; DME: dimethyl ether; LO-CAT: liquid-phase oxidation catalytic unit; LPG: liquefied petroleum gas. The green colour (in the online version of the paper) refers to the main input and output from the process. The red colour (online version) signifies the outputs from the process, including co-products.)

\subsection{Life cycle inventory}

All background LCA data have been obtained from the Ecoinvent database V3.3 (Moreno Ruiz et al., 2016), except for NPK fertilizers, which have been sourced from the agri-footprint database (Durlinger et al., 2014). The 2016 Spanish electricity mix has been considered in the analysis (REE, 2017). The storage of biogenic carbon is not included since the end-use of ethylene is not considered and it is not known how long the carbon would be stored before being released back to the atmosphere. However, the influence of carbon storage on the results is discussed in section 3.3.

\subsubsection{Biomass supply}

The inventory data for the biomass supply stage are summarised in Table 1. The data refer to the annual production of $1 \mathrm{Mt}$ of biomass (wet) needed for the chosen size of the ethylene plant (equivalent to the HHV of the feedstock of $500 \mathrm{MWth}$ ). The requirements for fertilizers, pesticides, diesel, electricity and the transport have been calculated following the biomass supply model described in Reyes Valle et al. (2015). The amounts of pesticides and their emissions to soil have been calculated according to Nemecek and Schnetzer (2012) and Sutter (2010). Emissions to water have been estimated using the average lixiviation fractions given in Franke et al. (2013). The concentration of metals in the fertilizers for the lixiviation calculations and the emissions to air from 
the use of fertilizers have been determined using data and methodologies proposed in Nemecek and Schnetzer (2012). According to these authors, the nutrients supplied to the soil are assumed to be taken up by the biomass or lost to the air or water, so the quantity of nutrients in the soil should not change in the long term. Therefore, no emissions to the soil from the use of fertilizers are considered.

Table 1 Life cycle inventory data for annual production of $1 \mathrm{Mt}$ (500 MWth) of poplar (wet)

\begin{tabular}{|c|c|c|}
\hline Category & Sub-category & Amount \\
\hline \multirow{2}{*}{ Fertilizers } & NPK (9-18-27) & $6,098 \mathrm{t} / \mathrm{y}$ \\
\hline & $\mathrm{N}$ fertilizer (ammonium nitrate) & $2,541 \mathrm{t} / \mathrm{y}$ \\
\hline \multirow[t]{3}{*}{ Pesticides } & Metil pirimifos (insecticide) & $6 \mathrm{t} / \mathrm{y}$ \\
\hline & Gliphosate (herbicide) & $50 \mathrm{t} / \mathrm{y}$ \\
\hline & Propineb (fungicide) & $4 \mathrm{t} / \mathrm{y}$ \\
\hline \multirow{16}{*}{$\begin{array}{l}\text { Diesel } \\
\text { Electricity } \\
\text { Emissions to air }\end{array}$} & & $843 t / y$ \\
\hline & & $20 \mathrm{MWh} / \mathrm{y}$ \\
\hline & Diesel emissions $^{a}$ & \\
\hline & Carbon dioxide & $2,630 \mathrm{t} / \mathrm{y}$ \\
\hline & Carbon monoxide & $9.58 \mathrm{t} / \mathrm{y}$ \\
\hline & Methane & $0.14 \mathrm{t} / \mathrm{y}$ \\
\hline & $\mathrm{NMVOC}^{\mathrm{b}}$ & $4.36 \mathrm{t} / \mathrm{y}$ \\
\hline & Nitrous oxide & $0.1 \mathrm{t} / \mathrm{y}$ \\
\hline & Nitrogen oxides & $37.11 \mathrm{t} / \mathrm{y}$ \\
\hline & Particulates & $3.77 \mathrm{t} / \mathrm{y}$ \\
\hline & Sulphur dioxide & $0.85 \mathrm{t} / \mathrm{y}$ \\
\hline & Ammonia & $16.8 \mathrm{~kg} / \mathrm{y}$ \\
\hline & Polycyclic aromatic hydrocarbons & $2.8 \mathrm{~kg} / \mathrm{y}$ \\
\hline & Ammonia $^{c}$ & $47 \mathrm{t} / \mathrm{y}$ \\
\hline & Nitrous oxide $^{c}$ & $24 t / y$ \\
\hline & Nitrogen oxides ${ }^{c}$ & $5 \mathrm{t} / \mathrm{y}$ \\
\hline \multirow[t]{8}{*}{ Emissions to water } & Nitrate & $615 \mathrm{t} / \mathrm{y}$ \\
\hline & Phosphate & $11 \mathrm{t} / \mathrm{y}$ \\
\hline & Cadmium & $13 \mathrm{~kg} / \mathrm{y}$ \\
\hline & Copper & $51 \mathrm{~kg} / \mathrm{y}$ \\
\hline & Zinc & $306 \mathrm{~kg} / \mathrm{y}$ \\
\hline & Lead & $20 \mathrm{~kg} / \mathrm{y}$ \\
\hline & Nickel & $59 \mathrm{~kg} / \mathrm{y}$ \\
\hline & Chromium & $195 \mathrm{~kg} / \mathrm{y}$ \\
\hline \multirow[t]{3}{*}{ Emissions to soil } & Metil pirimifos $^{d}$ & $6 \mathrm{t} / \mathrm{y}$ \\
\hline & Gliphosate $^{d}$ & $50 t / y$ \\
\hline & Propineb $^{d}$ & $4 \mathrm{t} / \mathrm{y}$ \\
\hline Transport & Feedstock to the production plant & $1.4 \cdot 10^{\prime} \mathrm{t} \cdot \mathrm{km} / \mathrm{y}$ \\
\hline
\end{tabular}

\subsubsection{Ethylene production}

The inventory data for the production stage are summarised in Table 2 for the three production routes considered. These data have been obtained through simulation in Aspen Plus (Haro et al., 2012, 2013; Villanueva et al., 2011). The simulations are based on the best available data from existing commercial (i.e. dehydration stage) and experimental plants. It can be seen from Table 2 that, for the same plant size (500 MWth), the requirements for biomass and the type and amount of co-products per tonne of ethylene are different for each route. 
Table 2 Life cycle inventory data for bio-ethylene production expressed per tonne of ethylene produced

\begin{tabular}{|c|c|c|c|c|c|}
\hline Category & Sub-category & $\begin{array}{l}\text { Unit per } \\
\text { tonne } \\
\text { ethylene }\end{array}$ & $\begin{array}{c}\text { Case 1: } \\
\text { Direct } \\
\text { ethanol } \\
\text { dehydration }\end{array}$ & $\begin{array}{c}\text { Case 2: } \\
\text { Indirect } \\
\text { ethanol } \\
\text { dehydration }\end{array}$ & $\begin{array}{c}\text { Case 3: } \\
\text { Dimethyl } \\
\text { ether to } \\
\text { olefins }\end{array}$ \\
\hline Biomass & Poplar wood (wet) & $\mathrm{kg}$ & 15,847 & 8,636 & 16,889 \\
\hline \multirow[t]{9}{*}{ Catalysts } & Alumina & $\mathrm{kg}$ & 0.20 & 0.35 & - \\
\hline & Co-Mo & $\mathrm{kg}$ & 0.11 & 0.07 & 0.12 \\
\hline & $\mathrm{Cu} / \mathrm{ZnO}$ & $\mathrm{kg}$ & - & 0.03 & - \\
\hline & CZA/HZSM-5 & $\mathrm{kg}$ & - & - & 8.4 \\
\hline & H-Mordenite & $\mathrm{kg}$ & - & 0.20 & - \\
\hline & Nickel & $\mathrm{kg}$ & 0.02 & 0.03 & - \\
\hline & $\mathrm{S}_{2} \mathrm{Mo}$ & $\mathrm{kg}$ & 0.52 & - & - \\
\hline & $\mathrm{ZnO}$ & $\mathrm{kg}$ & 0.54 & 0.70 & . \\
\hline & Zeolite & $\mathrm{kg}$ & - & - & 4.2 \\
\hline \multirow[t]{2}{*}{ Bed materials } & Sand & $\mathrm{kg}$ & - & 10.95 & \\
\hline & Zeolite & $\mathrm{kg}$ & 0.24 & 0.07 & 0.03 \\
\hline \multirow[t]{3}{*}{ Solvents } & $\mathrm{DEPG}^{\mathrm{a}}$ & $\mathrm{kg}$ & 2.37 & - & 1.60 \\
\hline & Monoethanolamine & $\mathrm{kg}$ & - & 3.74 & - \\
\hline & Diesel & $\mathrm{kg}$ & - & 35.82 & - \\
\hline \multirow[t]{4}{*}{ Other chemicals } & $\mathrm{KOH}$ & $\mathrm{kg}$ & 0.02 & 0.02 & 0.03 \\
\hline & Methanol & $\mathrm{kg}$ & - & - & 0.38 \\
\hline & Oxygen & $\mathrm{kg}$ & 8,511 & - & 8,423 \\
\hline & $\mathrm{NaOH}$ & $\mathrm{kg}$ & - & 0.03 & \\
\hline \multirow{2}{*}{ Water } & Power generation & $\mathrm{kg}$ & 1,900 & 10,017 & 1,904 \\
\hline & Process & $\mathrm{kg}$ & 2,365 & 31,458 & 866 \\
\hline \multirow{2}{*}{ Energy } & Electricity $^{\mathrm{b}}$ & MWh & 1.7 & 0.39 & 2.1 \\
\hline & Natural gas & $\mathrm{Nm}^{3 \mathrm{c}}$ & 84.0 & 84.0 & - \\
\hline \multirow[t]{6}{*}{ Emissions to air } & CO biogenic & $\mathrm{kg}$ & 352 & 0 & 137 \\
\hline & CO fossil & $\mathrm{kg}$ & 0.06 & 0.06 & - \\
\hline & $\mathrm{CO}_{2}$ biogenic & $\mathrm{kg}$ & 14,813 & 292 & - \\
\hline & $\mathrm{CO}_{2}$ fossil & $\mathrm{kg}$ & 179 & 9,452 & 14,795 \\
\hline & $\mathrm{SO}_{2}$ & $\mathrm{~kg}$ & 0.58 & - & 0.47 \\
\hline & $\mathrm{SO}_{3}$ & $\mathrm{~kg}$ & 0.01 & - & - \\
\hline Solid waste to & Biomass (chippings) & $\mathrm{kg}$ & 396 & 216 & 422 \\
\hline \multirow{3}{*}{ landfill $^{d}$} & Ash & $\mathrm{kg}$ & 100 & 65 & 106 \\
\hline & Spent catalysts & $\mathrm{kg}$ & $4.20^{\mathrm{d}}$ & $1.42^{\mathrm{d}}$ & $14.48^{\mathrm{d}}$ \\
\hline & Spent bed materials & $\mathrm{kg}$ & 0.24 & 0.07 & 0.03 \\
\hline $\begin{array}{l}\text { Wastewater to } \\
\text { treatment }\end{array}$ & & $\mathrm{kg}$ & 12,373 & 28,586 & 12,018 \\
\hline \multirow[t]{5}{*}{ Co-products } & Methanol (>98\%) & $\mathrm{kg}$ & 469 & - & - \\
\hline & Propanol (>98\%) & $\mathrm{kg}$ & 182 & - & - \\
\hline & Liquefied petroleum gas & $\mathrm{kg}$ & - & - & 357 \\
\hline & Propylene (>99.5\%) & $\mathrm{kg}$ & - & - & 871 \\
\hline & $\begin{array}{l}\text { Sulphur cake }(70 \% \\
\text { water) }\end{array}$ & $\mathrm{kg}$ & 3.59 & 2.45 & 3.85 \\
\hline Total production & Ethylene (>99.5\%) & $t / y$ & 65,966 & 121,048 & 61,896 \\
\hline
\end{tabular}

${ }^{a}$ DEPG: dimethyl ethers of polyethylene glycol.

${ }^{\mathrm{b}}$ Net energy consumption after subtracting the total electricity consumed from the electricity produced.

${ }^{\mathrm{C}} \mathrm{Nm}^{3}$ : normal cubic meter at standard pressure and temperature.

${ }^{d} 1.20 \mathrm{~kg}$ (Case 1), $1.02 \mathrm{~kg}$ (Case 2) and $8.48 \mathrm{~kg}$ (Case 3) of which is hazardous waste.

\subsubsection{Allocation}

As the ethylene production system produces several co-products, it is necessary to allocate the environmental burdens between them. As shown in Table 2, the co-products in each case are:

- Case 1: methanol, propanol and sulphur cake;

- Case 2: sulphur cake; and

- Case 3: liquefied petroleum gas (LPG), propylene and sulphur cake. 
Following the ISO 14040/44 guidelines (ISO, 2006a, 2006b), system expansion has been applied first. However, a sensitivity analysis is included, considering energy and economic allocation, to explore the effect on the results of the allocation approach and ensure the robustness of the conclusions. For system expansion, the system has been credited for avoiding the production of the above co-products in other production systems; the data for these production systems have been sourced from Ecoinvent. For energy and economic allocation, the impacts have been allocated between ethylene and the co-products based on their HHV values and market prices in 2014, respectively; these values can be found in Table 3. The proportion of environmental burdens allocated to ethylene is summarised in Table 4. The economic value of sulphur cake is considered negligible because it is suitable for agricultural purposes but is undesirable as a chemical feedstock (NREL, 2006). Similarly, as it is not used for energy purposes due to the high water content, its HHV has not been considered. Hence, no burdens have been allocated to this coproduct. However, the system has been credited for displacing the sulphur fertilizer.

Table 3 Values used for energy and economic allocation

\begin{tabular}{lccc}
\hline Output & $\begin{array}{c}\text { Co-product } \\
\text { (kg/t ethylene) }\end{array}$ & $\begin{array}{c}\mathbf{H H V}^{\mathrm{a}} \\
(\mathbf{M J} / \mathbf{k g})\end{array}$ & $\begin{array}{c}\text { Price } \\
(\mathbf{\epsilon} / \mathbf{t})\end{array}$ \\
\hline Ethylene & - & 50.2 & $1000^{\mathrm{b}}$ \\
Methanol & 469 & 22.6 & $275^{\mathrm{b}}$ \\
Propanol & 182 & 33.6 & $3750^{\mathrm{b}}$ \\
Propylene & 871 & 48.8 & $1050^{\mathrm{b}}$ \\
LPG & 357 & $49.6^{\mathrm{c}}$ & $862^{\mathrm{d}}$ \\
\hline
\end{tabular}

${ }^{a}$ Aspen (2007).

b ICIS Pricing Data (2014).

${ }^{c}$ Based on liquefied petroleum gas (LPG) composition (\% wt): $2.9 \%$ ethylene, $28.8 \%$ ethane, 18.5\% propane, $2.8 \%$ propylene and butenes.

${ }^{d}$ Regulated price in Spain (BOE, 2014).

Table 4 Percentage of environmental impact allocated to bio-ethylene

\begin{tabular}{lccc}
\hline $\begin{array}{l}\text { Allocation } \\
\text { basis }\end{array}$ & $\begin{array}{c}\text { Case 1: } \\
\text { Direct ethanol } \\
\text { dehydration }\end{array}$ & $\begin{array}{c}\text { Case 2: } \\
\text { Indirect ethanol } \\
\text { dehydration }\end{array}$ & $\begin{array}{c}\text { Case 3: } \\
\text { Dimethyl ether } \\
\text { to olefins }\end{array}$ \\
\hline Energy & $75.0 \%$ & $100 \%$ & $45.5 \%$ \\
Economic & $55.2 \%$ & $100 \%$ & $45.0 \%$ \\
\hline
\end{tabular}

\subsubsection{Comparison with other production routes and sources of ethylene}

To put the results in perspective, the environmental impacts of thermo-chemical bio-ethylene are compared with two alternatives: ethylene from fossil resources and from ethanol made using firstgeneration crops. The former is currently the main source of ethylene, produced via steam cracking of hydrocarbons (Mohsenzadeh et al., 2017). For bio-ethanol, the most prevalent feedstock in Europe is sugar beet (Clifford, 2017). Muñoz et al. (2014) reported that sugar beet had the lowest environmental impacts for ethanol production via fermentation in comparison with other feasible crops in Europe, such as maize and wheat. Hence, this feedstock has been considered for the comparison. The inventory data for both fossil and sugar beet-derived ethylene have been sourced from Ecoinvent. The data for ethanol dehydration have been obtained through process modelling as described in section 2.2.2.

\subsection{Impact assessment}

The SimaPro v.8.3. software (Pré Consultants B.V., 2017) has been used for the life cycle modelling and the impacts have been calculated following the CML 2 method (Guinée et al. 2001), using the April 2016 update. All 11 impacts included in the CML 2 method have been considered: abiotic depletion potential of elements $\left(A D P_{\text {elements }}\right)$, abiotic depletion potential of fossil fuel resources $\left(A P_{\text {fossil }}\right)$, global warming potential $(G W P)$, ozone depletion potential (ODP), human toxicity potential (HTP), freshwater aquatic ecotoxicity potential (FAETP), marine aquatic ecotoxicity potential (MAETP), terrestrial ecotoxicity potential (TETP), photochemical oxidants creation potential (POCP), acidification potential (AP) and eutrophication potential (EP). 


\section{Results and discussion}

This section compares the environmental impacts of the three routes considered, first for system expansion and then for the energy-based and economic allocation. This is followed by comparison with the production of ethylene using first-generation bio-ethanol and steam cracking of fossil resources.

\subsection{Comparison of thermo-chemical routes for system expansion}

As shown in Figure 7, when system expansion is applied, Case 2 (indirect ethylene dehydration) is the best option for eight out of 11 impacts considered. This is despite the credits for avoiding the production of sulphur fertilizer being negligible. The reason for its superior performance is the lower consumption of biomass and electricity per tonne of bio-ethylene produced compared to Cases 1 and 3 (see Table 2). For the remaining three impacts (ADP fossil, GWP and ODP), Case 3 (DME to olefins) is the preferred alternative.

The ethylene production stage is the main contributor to the impacts for all three routes for ten out of the 11 impact categories. The exception is the bioslurry production with almost a negligible contribution because this stage is energy self-sufficient and no chemicals or catalysts are used. Only for the TETP is the biomass supply a major contributor because of the use of pesticides. The contribution of the agricultural stage is generally lower in Case 2 across the impacts due to the higher ethylene production per tonne of biomass.

For all three cases, the use of catalyst metals, such as Mo, $\mathrm{Cu}$ and, to a lesser extent, $\mathrm{Zn}$ and Ni,

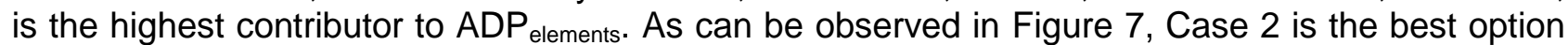
for this impact. The reason for that is that ethanol synthesis in Case 2 is based on non-metallic catalyst (H-mordenite). In Case 2, 62\% of the impact is from the use of Mo in the Co-Mo catalyst in the guard bed for reducing the sulphur concentration. Most of the impact in Case $1(93 \%)$ comes from $\mathrm{Mo}$ in the $\mathrm{S}_{2} \mathrm{Mo}$ catalyst used in the synthesis reactor and in the Co-Mo catalyst of the sour water-gas shift reactor. Finally, for Case 3, $87 \%$ of the impact is related to $\mathrm{Zn}$-CuO catalyst in the DME synthesis reactor.

Cases 1 and 3 have lower values for ADP fossil, GWP and ODP than Case 2 due to the system credits for avoiding the production of their respective co-products in other processes. Case 3 is the best option with the negative net values for these three categories: $-62.4 \mathrm{GJ} / \mathrm{t}\left(\mathrm{ADP}_{\text {fossil }}\right),-0.07 \mathrm{t}$ $\mathrm{CO}_{2}$ eq. $/ \mathrm{kg}$ (GWP), and $-59 \mathrm{mg}$ CFC-11 eq./t (ODP). Propanol is the main source of the credits for ADP $_{\text {fossil }}(94 \%)$, GWP (98\%) and ODP $(96 \%)$ in Case 1. In Case 3, credits are mainly coming from Propylene for ADP $_{\text {fossil }}(74 \%)$ and GWP (85\%), and from LPG for ODP (almost 100\%). Without considering the system credits, electricity is responsible for most of the impacts in Case 3 , with contributions of $67 \%-78 \%$ for these three impacts. In Case 1, these three impacts are from electricity (49\%-60\%) and from natural gas in the ethanol dehydration stage (18\%-28\%). Finally, in Case 2, the main contributors to these three categories are natural gas used in ethanol dehydration (29\%-40\%), electricity (20\%-25\%) and the diesel used as the sorbent in the OLGA process for biochar removal and then subsequently burned in the biochar combustor (17\%-23\%). The lower consumption of electricity in Case $2(0.39 \mathrm{MWh} / \mathrm{t})$ relative to Cases 1 and 3 (1.7 and 2 $\mathrm{MWh} / \mathrm{t}$ ) is because ethanol production is energy self-sufficient, with all the electricity (and natural gas) consumed in Case 2 supplied from the ethanol dehydration stage.

Case 2 is the best option for HTP, FAETP and MAETP. As mentioned earlier, this is due to the lower consumption of electricity, metal catalysts and pesticides, the latter related to the lower use of biomass per unit of product compared to Cases 1 and 3 . The main contributors to these impacts in Case 2 are MEA used for $\mathrm{CO}_{2}$ capture (66\% of HTP), pesticides (32\% of FAETP) and electricity (55\% of MAETP). For Case 1, electricity is responsible for $25 \%$ of HTP, $17 \%$ of FAETP and $50 \%$ of MAETP. The use of the molybdenum catalyst in the synthesis reactor and the guard bed contributes $38 \%-48 \%$ to the three toxicity impacts and the use of pesticides $19 \%$ to FAETP. In Case 3 , electricity contributes $20 \%-59 \%$ to these impacts categories. The use of the $\mathrm{Cu}-\mathrm{ZnO}$ catalyst is responsible for $27 \%-49 \%$ while $17 \%$ of FAETP is due to the use of pesticides in the feedstock. Although Case 2 has lower HTP than Cases 1 and 3, the main reason for this impact 
are carcinogenic substances, specifically, ethylene oxide emitted in the manufacturing process of MEA.

The agricultural stage is the major contributor to TETP in all three cases $(>80 \%)$. Almost all of the impact (98\%) derives from the use of pesticides. Case 2 is the best option because of the lower amount of biomass required per tonne of ethylene produced.

Case 2 is also the best option for POCP. Cases 1 and 3 have a much higher impact (46 and 29 times, respectively), almost all of which is due to the higher $\mathrm{CO}$ emissions associated with the Selexol process. This impact is higher for Case 1 than Case 3 because the gas flow in the Selexol process is higher for the former as it includes the recirculation stream of the synthesis loop in addition to the raw synthesis gas stream.

Finally, Case 2 is also the best option for AP and EP. This is due to the lower electricity consumption and biomass requirements than in Cases 1 and 3 . The main contributors to EP in Case 2 are the make-up water used in the steam power cycle $(30 \%)$, fertilizers $(29 \%)$ and electricity consumption (17\%). Fertilizers and electricity also cause $30 \%$ and $33 \%$ of AP. In Case 1 , $52 \%$ of the AP and $37 \%$ of the EP are related to electricity consumption. The use of fertilizers adds a further $24 \%$ and $32 \%$, respectively. Similarly, for Case 3, electricity and the fertilizers are responsible for $60 \%$ and $28 \%$ of AP and $48 \%$ of $19 \%$ of EP, respectively.

Further details on the contribution to the impacts of different categories (shown in Table 2) can be found for each production route in Tables S1-S3 in the SI.

\subsection{Sensitivity analysis of allocation approaches}

If the environmental burdens are allocated on the energy basis (Figure 8), Case 2 is the best option for five impacts (ADP elements, FAETP, MAETP, POCP and AP) and Case 3 for three $\left(\mathrm{ADP}_{\text {fossil }}\right.$, GWP and ODP). Three other categories (HTP, TETP and EP), which are similar for these two options, are also lower than for Case 1, which in turn is the worst alternative for ten out of 11 categories considered.

For allocation on the economic basis (Figure 9), Case 2 has the lowest impacts for the same five categories as for energy allocation (ADP elements, FAETP, MAETP, POCP and AP). These values are the same as for the energy allocation as there are no co-products with energetic or economic value in Case 2. For Case 3, the impacts for economic and energy allocation are almost identical because, by coincidence, the allocation factors are very similar (45.5\% and $45 \%$; see Table 4$)$. Case 3 is again the best option for ADP $_{\text {fossil }}$, GWP and ODP. On the other hand, all impacts for Case 1 show a $26 \%$ reduction with respect to energy allocation. This is due to the allocation factors changing from $75 \%$ to $55 \%$ for the economic allocation. This change is a consequence of the higher price of propanol with respect to ethylene (3750 €/t of propanol vs $1000 € / \mathrm{t}$ of ethylene) while ethylene has a higher HHV value $(50.2 \mathrm{MJ} / \mathrm{kg}$ vs $33.6 \mathrm{MJ} / \mathrm{kg}$ for propanol). Case 1 is still the worst option for POCP. Case 2 is the least preferred alternative for three categories $\left(\mathrm{ADP}_{\text {fossil, }}\right.$, GWP and ODP) while Case 3 has the highest ADP elements. Cases 1 and 2 have the highest impacts with similar values for FAETP, MAETP and AP. For the remaining three categories (HTP, TETP and EP), all three cases have similar values.

Case 2 is ranked top for five impacts (ADP elements, FAETP, MAETP, POCP and AP) and Case 3 for three $\left(\mathrm{ADP}_{\text {fossil, }}\right.$ GWP and ODP) regardless of the method used. Case 2 is also the top ranked alternative for HTP for system expansion and energy allocation, while Case 1 is the best option for economic allocation. For the remaining two impacts (TETP and EP), the top ranking position for system expansion changes from Case 2 to Case 3 if energy or economic allocation is used.

Therefore, the sensitivity analysis of allocation approaches shows that, while the absolute values of the impacts change, the allocation method has little influence on the best-ranking options. Thus, it can be concluded that the results are robust with respect to different allocation methods. 


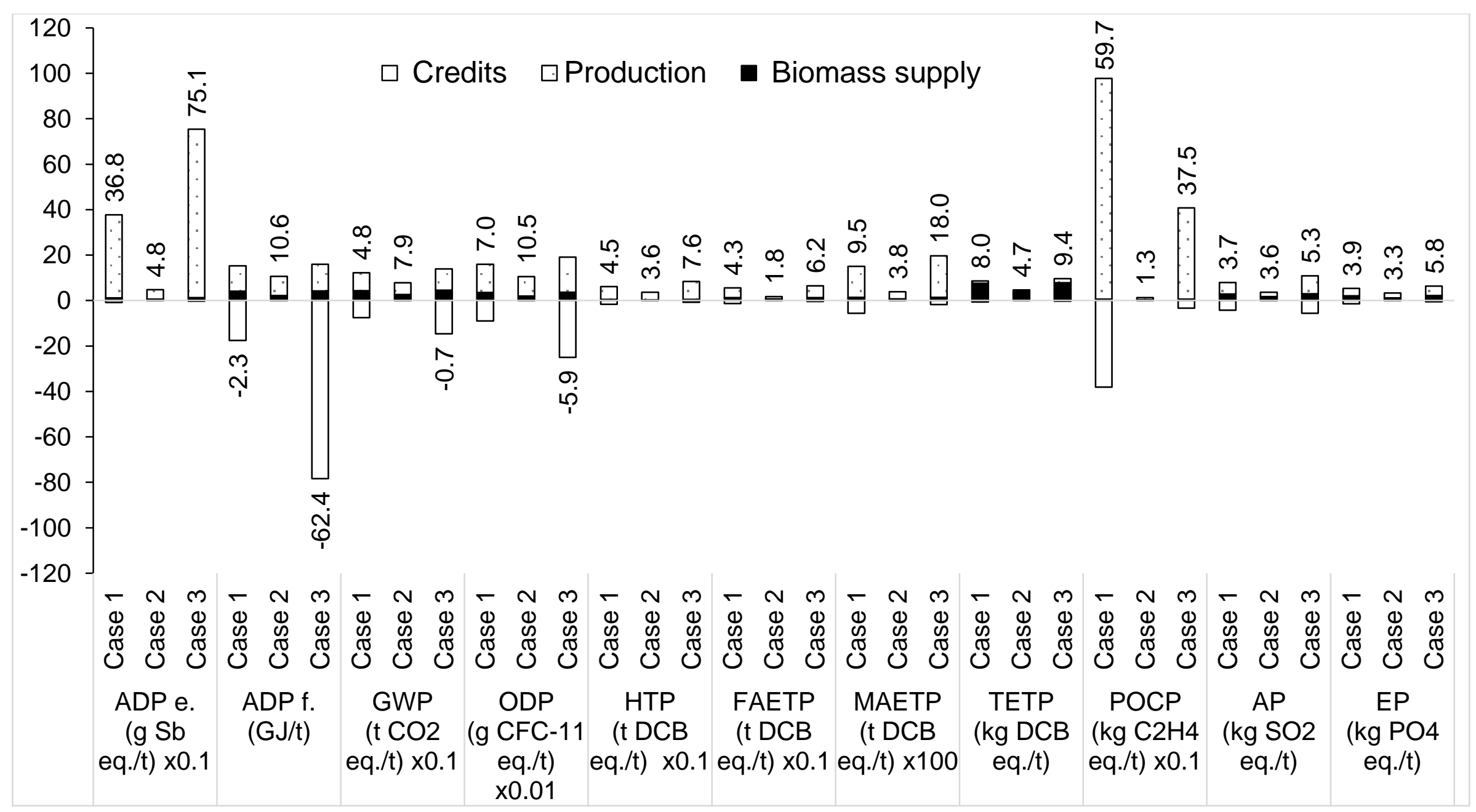

Figure 7 Life cycle environmental impacts of bio-ethylene produced via three thermo-chemical routes for system expansion.

(Case 1: direct ethanol dehydration; Case 2: indirect ethanol dehydration; Case 3: dimethyl ether (DME) to olefins. The values shown on top of each bar represent the total impact after the system credits have been applied. Some impacts have been scaled to fit. To obtain the original values, multiply by the factor shown on the $x$-axis for the relevant impacts. ADP e.: abiotic depletion potential of elements, ADP f.: abiotic depletion potential of fossil resources, GWP: global warming potential, ODP: ozone layer depletion potential, HTP: human toxicity potential, FAETP: freshwater aquatic ecotoxicity potential, MAETP: marine aquatic ecotoxicity potential, TETP: terrestrial ecotoxicity potential, POCP: photochemical oxidants creation potential, AP: acidification potential, EP: eutrophication potential). 


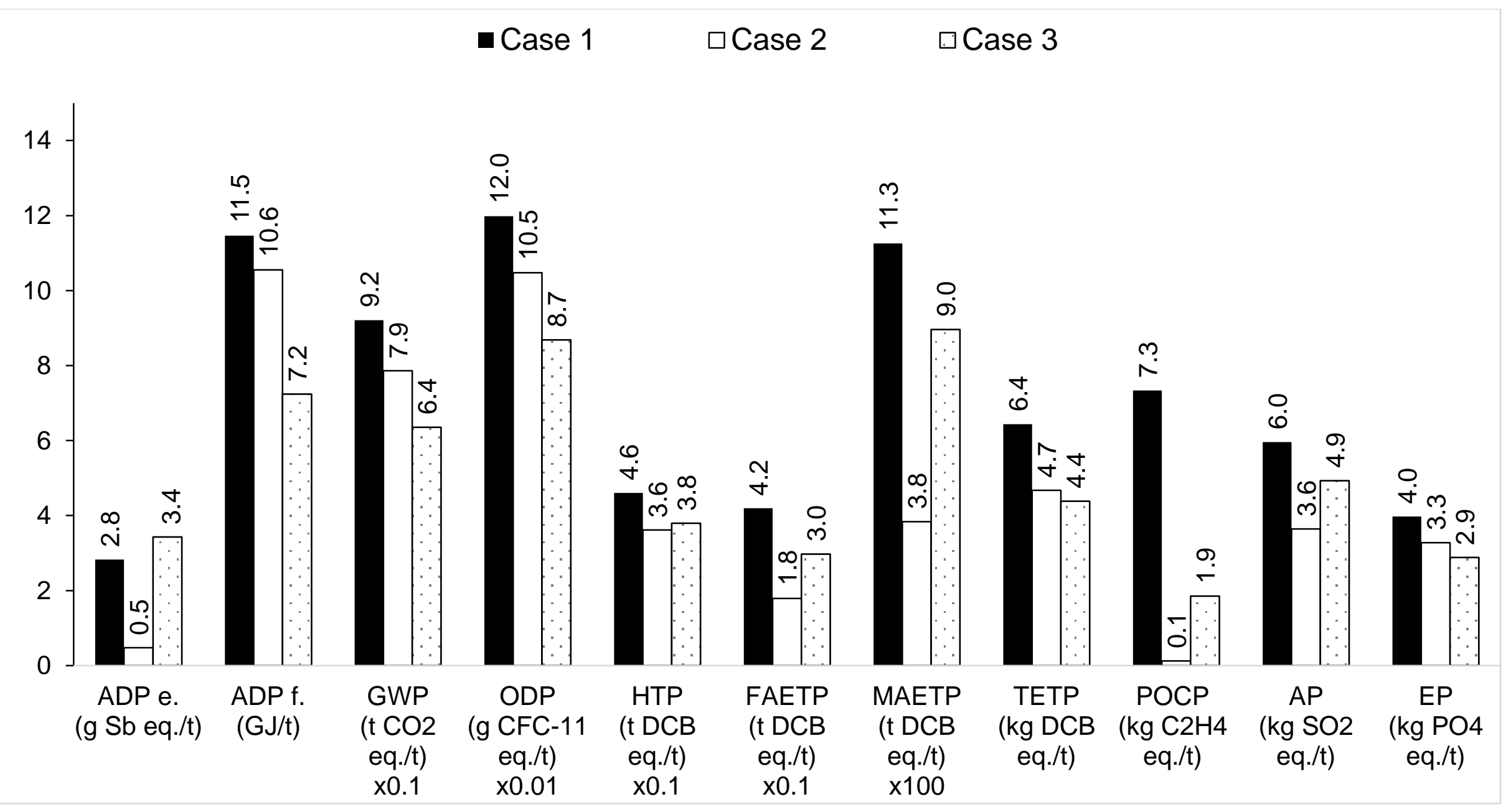

Figure 8 Life cycle environmental impacts of bio-ethylene produced via three thermo-chemical routes for allocation on the energy basis.

(Energy basis: higher heating value. Case 1: direct ethanol dehydration; Case 2: indirect ethanol dehydration; Case 3: dimethyl ether (DME) to olefins. For the impacts nomenclature, see Figure 7. Some impacts have been scaled to fit. To obtain the original values, multiply by the factor shown on the $x$-axis for the relevant impacts.) 


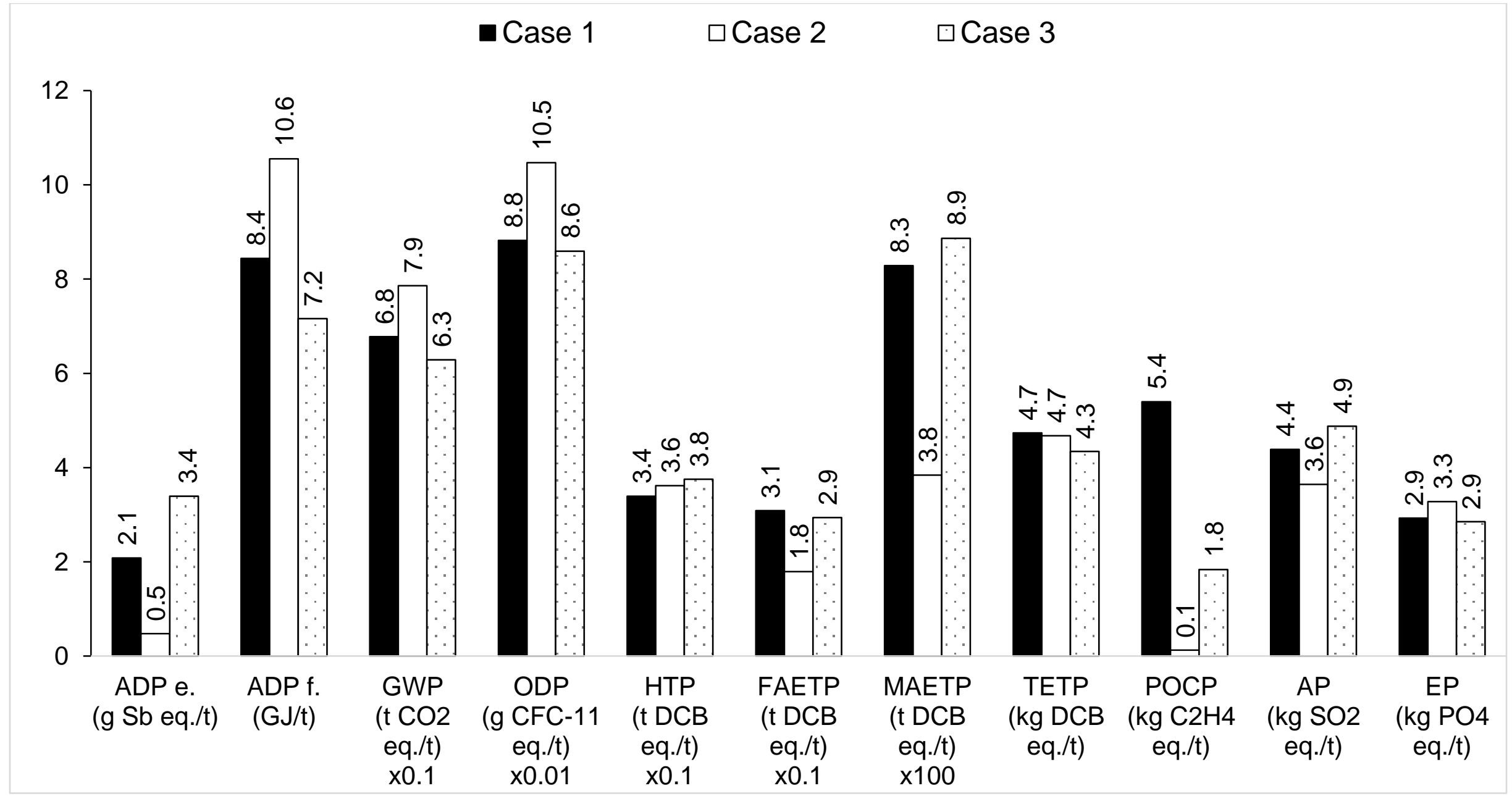

Figure 9 Life cycle environmental impacts of bio-ethylene produced via three thermo-chemical route for allocation on the economic basis.

(Economic basis: market prices of ethylene and the co-products. Case 1: direct ethanol dehydration; Case 2: indirect ethanol dehydration; Case 3: dimethyl ether (DME) to olefins. For the impacts nomenclature, see Figure 7 . Some impacts have been scaled to fit. To obtain the original values, multiply by the factor shown on the $\mathrm{x}$-axis for the relevant impacts.) 


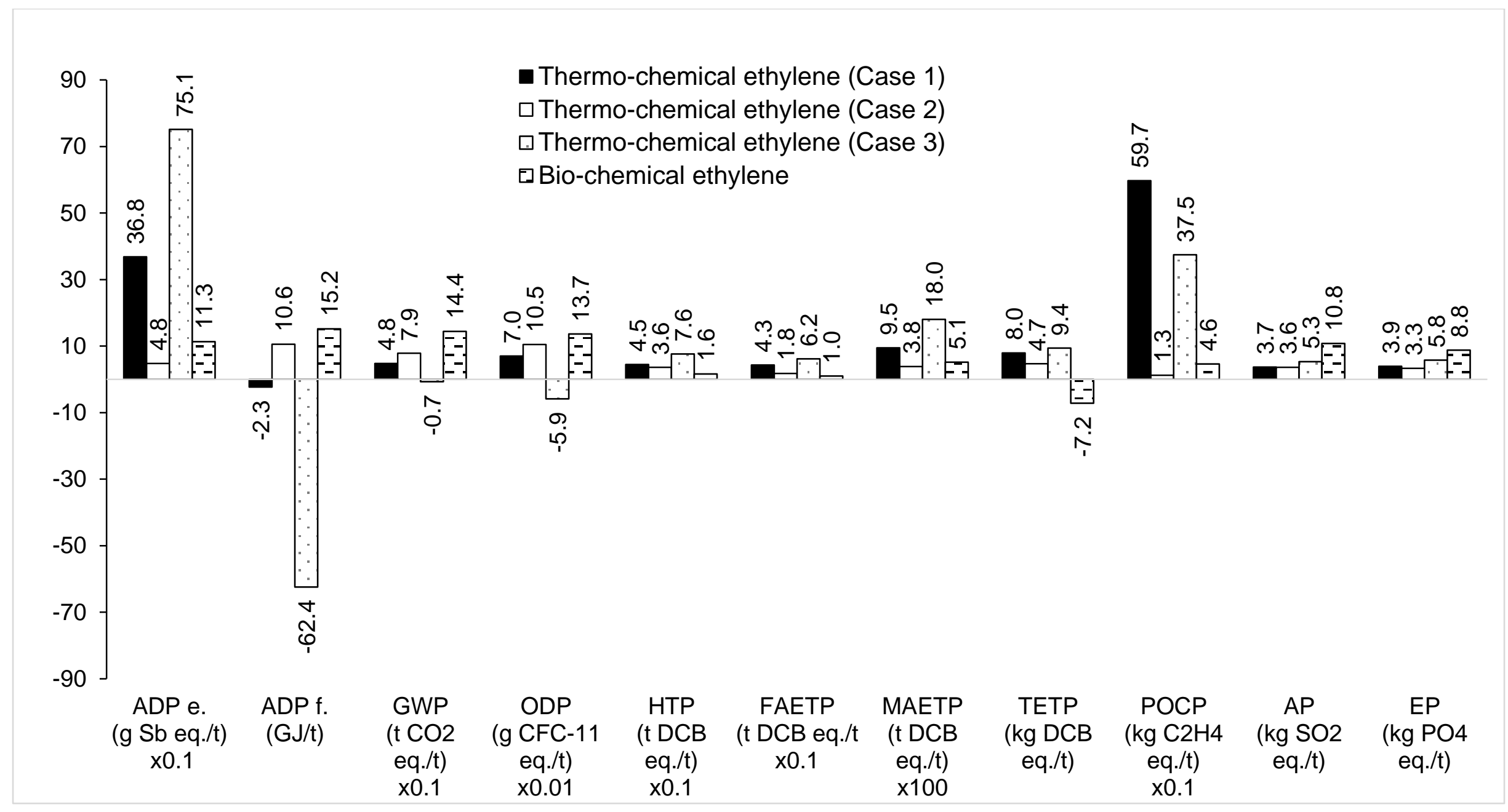

Figure 10 Comparison of thermo-chemical and bio-chemical bio-ethylene for system expansion.

(Case 1: direct ethanol dehydration; Case 2: indirect ethanol dehydration; Case 3: dimethyl ether (DME) to olefins. Bio-chemical ethylene: dehydration of ethanol produced from sugar beet by fermentation. For the impacts nomenclature, see Figure 7 . Some impacts have been scaled to fit. To obtain the original values, multiply by the factor shown on the $\mathrm{x}$-axis for the relevant impacts.) 


\subsection{Comparison of thermo-chemical and bio-chemical ethylene}

Figure 10 shows that, for system expansion, the bio-chemical route using sugar beet as the feedstock for ethanol, is a better option than the thermo-chemical route for only three impacts across the three cases considered: HTP, FAETP and TETP. For the remaining eight impacts, it is less sustainable than at least one of the thermo-chemical cases.

The higher $\mathrm{ADP}_{\text {fossil, }}$ GWP and ODP for the bio-chemical route than any of the three thermochemical cases are due to the heat demand in the biological reactor, supplied mainly by fossil-fuel resources, and the higher specific biomass consumption per tonne of ethylene involving higher diesel consumption in the agricultural activities. GWP is also higher due to the higher emissions of nitrous oxide from the use of fertilizers. The higher values of AP and EP are related respectively to the higher emissions of ammonia to air and nitrate to water from the use of fertilizers for sugar beet than for poplar.

For $\mathrm{ADP}_{\text {elements, }}$ MAETP and POCP, bio-chemical ethylene has higher impacts than Case 2 but lower than Cases 1 and 3. For $\mathrm{ADP}_{\text {elements, }}$ the higher impact than for Case 2 is due to the higher consumption of pesticides and biocides for the sugar beet and the higher biomass requirement per unit of ethylene produced. The lower impact with respect to Cases 1 and 3 is related to their utilization of metal catalysts. The higher MAETP and POCP relative to Case 2 is due to the heat consumed in the fermentation reactor. Cases 1 and 3 show higher values for MAETP and POCP because of the higher electricity consumption and CO emissions from Selexol, respectively.

\subsection{Comparison of thermo-chemical bio-ethylene and fossil-based ethylene}

Compared to ethylene from fossil resources, thermo-chemical bio-ethylene reduces ADP $_{\text {fossil }}$ by $84 \%-196 \%$ and GWP by $66 \%-105 \%$ across the three cases considered (Figure 11). These results are not surprising given the use of biomass for bio-ethylene. Furthermore, the electricity consumption per unit ethylene produced is lower for bio-ethylene (0.39-2.1 MWh/t; see Table 2) than for its fossil-based equivalent (3.5-6.8 MWh/t (Deloite, 2013)). In addition, the reduction in these two impacts is greater for Cases 1 and 3 due to the credits for the coproducts.

The reduction in GWP would be much higher if the biogenic carbon storage in bio-ethylene was considered, due to the carbon sequestration by the feedstock. If all the carbon contained in 1 tonne of bio-ethylene is considered as stored carbon, $3.14 \mathrm{t} \mathrm{CO}_{2}$ eq./t would need to be subtracted from the GWP values shown in Figure 9 for each of the three routes. In that case, the GWP would range from $-3.21 \mathrm{t} \mathrm{CO}_{2}$ eq./t for Case 3 to $-2.36 \mathrm{t} \mathrm{CO}_{2}$ eq./t for Case 2 . However, these potential savings in GHG should be interpreted with caution as processing of ethylene into an end product would lead to additional GHG emissions and, depending on the type of the product and its longevity, potential release of the stored carbon back to the atmosphere.

Extrapolating the results (without considering biogenic carbon) to the global levels, and assuming that $20 \%$ of the demand of $150 \mathrm{Mt} / \mathrm{y}$ (Mitsubishi Chemical, 2017) is supplied by thermo-chemical bio-ethylene, would lead to the reductions in GWP shown in Figure 12. These reductions have been calculated considering the current supply of fossil-based ethylene. For system expansion, the savings would range from $18,300 \mathrm{kt} \mathrm{CO}_{2}$ eq./y in Case 2 to $43,950 \mathrm{kt} \mathrm{CO}_{2}$ eq./y in Case 3. The latter is higher than the annual $\mathrm{CO}_{2}$ eq. emissions of Sweden in 2015 (JRC, 2017). These savings would be reduced by almost two times for the energy and 22\%-48\% for the economic allocation for Cases 1 and 3 (there would be no change for Case 2 due to insignificant credits for the sulphur as fertilizer).

However, six other impacts would be higher for bio-ethylene than its equivalent produced by

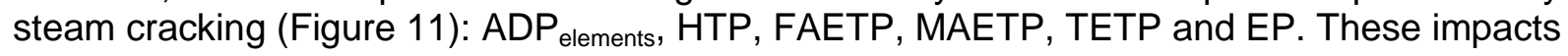


would increase from three (MAETP) to 39 times $\left(\mathrm{ADP}_{\text {elements }}\right)$ due to the use of metal catalysts, pesticides, fertilizers and MEA which are not required in the production of ethylene from fossil resources. For POCP, Cases 1 and 3 have higher POCP values than fossil-based ethylene (16 and 3.5 times, respectively) because of the $\mathrm{CO}$ emissions from the Selexol process. However, the fossil option has a higher impact than Case 2 due to methane leakage from the equipment, pipes, etc. (Berdowski et al., 1995). Furthermore, ODP is higher for Cases 1 and 2 (17 and 25 times) but Case 3 has a 14.6 times lower impact due to the system credits. Finally, Cases 1 and 2 have a similar AP to the fossil option, which is lower than the value in Case 3. These impacts could be reduced by developing more efficient catalysts with longer lifespans. This would reduce the biomass requirements per tonne of ethylene and reduce the amount of both the catalyst needed and solid waste generated at the end of its useful lifetime.

In summary, switching from fossil to bio-ethylene would lead to substantial reductions in GWP but would also increase significantly a number of other impacts. This is congruent with the results in Liptow et al. (2015), who reported lower GWP and POCP but higher EP and AP for bio-ethylene from wood produced via thermo-chemical route (methanol to olefins) compared to ethylene from fossil resources. Case 3 offers the greatest potential for reducing GWP (105\%) but it also has higher impacts for six other categories. Case 2 also provides a considerable reduction in GWP (44\%) but shows a lower or no increase in other categories compared to ethylene from fossil resources.

\section{Conclusions}

This paper has discussed the environmental performance of three thermo-chemical processes for ethylene production from a lignocellulosic feedstock: direct and indirect dehydration of ethanol and dimethyl (DME)-to-olefins route. Three approaches have been considered for apportioning the impacts among the co-products: system expansion, and energy and economic allocation.

When system expansion is applied, the indirect route (Case 2) has the lowest values for eight out of the 11 impact categories (ADP elements, HTP, FAETP, MAETP, TETP, POCP, AP and EP), mostly because of the lower requirement of biomass, catalysts and electricity per unit of bio-ethylene produced. On the other hand, the DME-to-olefins route (Case 3) has the lowest impacts for GWP, ADP fossil and ODP due to the system credits for the co-products. Similar conclusions regarding the best alternative are reached when energy or economic allocation is applied. The main difference with the results from system expansion is that the direct dehydration route (Case 1) is the worst option for most of the impact categories for energy allocation due to the lower energy content of the co-product methanol compared to ethylene.

Compared to bio-chemical ethylene produced from sugar-beet ethanol, the indirect route reduces the impacts by $23 \%-73 \%$ for most categories, except for HTP, FAETP, and TETP. The other two thermo-chemical routes have lower ADP $_{\text {fossil, }}$ ODP, GWP and, to a lesser extent, AP and EP. However, bio-chemical ethylene is the best option for FAETP, HTP and TETP, POCP and ADP elements.

All the thermo-chemical processes offer a great potential for reducing GWP (44\%-105\%) and $\mathrm{ADP}_{\text {fossil }}(104 \%-196 \%)$ relative to ethylene produced from fossil resources. However, for most of the other categories, bio-ethylene has higher impacts. Therefore, the substitution of ethylene produced from fossil fuel resources with thermo-chemical bio-ethylene to reduce greenhouse gas emission could result in an increase in other environmental impacts. 


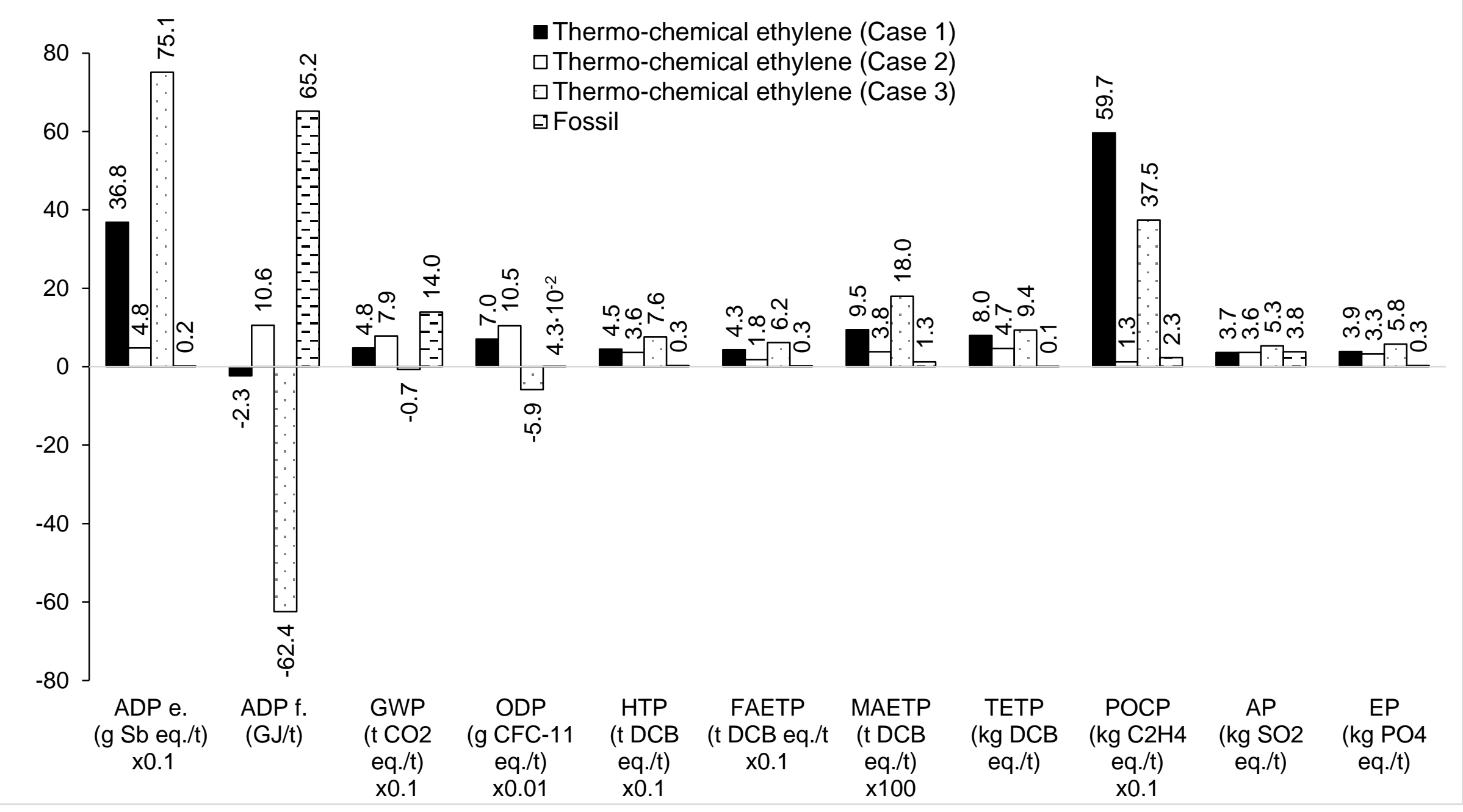

Figure 11 Comparison of thermo-chemical bio-ethylene and fossil-based ethylene for system expansion.

(Case 1: direct ethanol dehydration; Case 2: indirect ethanol dehydration; Case 3: dimethyl ether (DME) to olefins. Fossil: steam cracking. For the impacts nomenclature, see Figure 7. Some impacts have been scaled to fit. To obtain the original values, multiply by the factor shown on the $x$-axis for the relevant impacts.) 


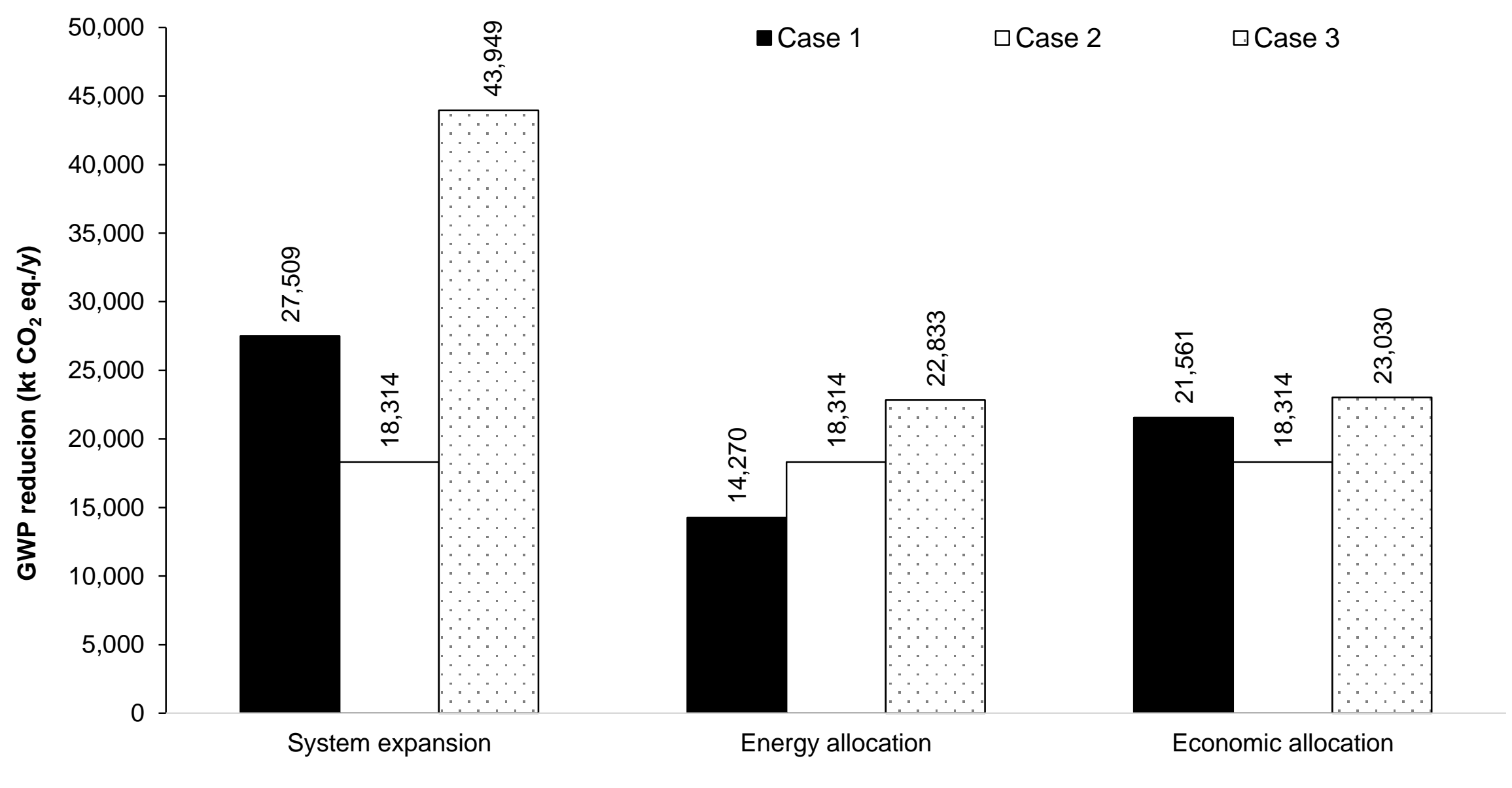

Figure 12 Reduction in global warming potential (GWP) assuming $20 \%$ of the global demand was supplied by thermo-chemical bioethylene instead of fossil-based ethylene.

(The rest of the demand supplied by ethylene produced by steam cracking. Case 1: direct ethanol dehydration; Case 2: indirect ethanol dehydration; Case 3: dimethyl ether (DME) to olefins. For the impacts nomenclature, see Figure 7.) 


\section{Acknowledgements}

Bernabé Alonso-Fariñas thanks the members of the Sustainable Industrial Systems research group for their kind support during his post-doctoral stay at the University of Manchester. Pedro Haro is grateful to the Universidad de Sevilla for the post-doctoral Grant Contrato de Acceso al Sistema Español de Ciencia, Tecnología e Innovación (VPPI-US).

\section{References}

Amghizar, I., Vandewalle, L.A., Van Geem, K.M., Marin, G.B., 2017. New Trends in Olefin Production. Engineering. 3(2), 171-178. https://doi.org/10.1016/J.ENG.2017.02.006

Arvidsson, M., 2016. Assessing Integrated Gasification-Based Biorefinery Concepts for Decarbonisation of the Basic Chemicals Industry. Industrial Energy Systems and Technologies, Department of Energy and Environment, Chalmers University of Technology. Göteborg. ISBN 978-91-7597-410-1

Aspen, 2007. Aspen Physical Property System. Physical Property Methods, Aspen Technology.

Becerra, J., Figueredo, M., Cobo, M., 2017. Thermodynamic and economic assessment of the production of light olefins from bio-ethanol. Journal of Environmental Chemical Engineering 5(2), 1554-1564. https://doi.org/10.1016/j.jece.2017.02.035

Belboom, S., and Léonard, A., 2016. Does biobased polymer achieve better environmental impacts than fossil polymer? Comparison of fossil HDPE and biobased HDPE produced from sugar beet and wheat. Biomass \& Bioenergy 85:159-167. https://doi.org/10.1016/j.biombioe.2015.12.014

Berdowski, J. J. M., van der Most, P.F.J., Mulder, W., 1995. Production proccess-Ethylene, code 040501. TNO Company. The Netherlands.

BOE, 2014. Spanish Official Gazette (in Spanish). 145-6339 pp 45187-45189. Available at http://www.boe.es.

Braskem Company, 2017. http://www.braskem.com/site.aspx/lm-greenTM-Polyethylene

Cheali, P., Posada, J.A., Gernaey, K.V., Sin, G., 2015. Upgrading of lignocellulosic biorefinery to value-added chemicals: Sustainability and economics of bio-ethanol$\begin{array}{lllll}\text { derivatives. Biomass } \quad \& \quad \text { Bioenergy } & \text { 282-300. }\end{array}$ https://doi.org/10.1016/i.biombioe.2015.02.030

Chematur Engineering $\mathrm{AB}, 2017 . \quad$ Ethylene from ethanol. Available at: http://chematur.se/downloads.

Clifford, C.B, 2017. EGEE 439, Alternative fuels from biomass sources, 7.1 Ethanol production-general information. PennState College of Earh and Meneral Sciences and John A. dutton e-Education Institute. Available at: https://www.eeducation.psu.edu/egee439/node/646.

Deloite, 2013. Report on Developing Baseline Specific Energy Consumption in Petrochemicals Industry in India. www.deloitte.com/in.

Durlinger, B., Tyszler, M., Scholten, J., Broekema, R., Blonk, H., 2014. Agri-Footprint; a Life Cycle Inventory database covering food and feed production and processing. Proceedings of the 9th International Conference on Life Cycle Assessment in the AgriFood Sector (LCA Food 2014), 8-10 October 2014, San Francisco, USA. ACLCA, Vashon, WA, USA. ISBN: 978-0-9882145-7-6. Available at: http://lcacenter.org/lcafood2014/proceedings/LCA Food 2014 Proceedings.pdf

DSBC, 2012. Dutch Sustainable Biomass Commission (Commissie Duurzaamheidsvraagstukken Biomassa). Sustainable biomass in the chemical industry. The Netherlands Deloitte, 2013. Report on Developing Baseline Specific Energy Consumption in Petrochemicals Industry in India. Available at:www.deloitte.con/in

ECOBION project, 2009. Compared life cycle assessments of biomass feedstocks at subregional scale Livrable L7 - Résultats. Agro ParisTech, INRA, PNRB.

Ethylene Profile, 2015. ICIS Chemical Business. 27 July-9 August. Page 32. 
Fiorentino, G., Ripa, M., Ulgiati, S., 2017. Chemicals from biomass: Technological versus environmental feasibility. A review. Biofuels, Bioproducts and Biorefining 11(1), 195-214. https://doi.org/10.1002/bbb.1729

Franke, N.A., Boyaciosglu, H., Hoekstra, A.Y., 2013. Grey water footprint accounting. Tier 1 Supporting guidelines. Value of Water, Research report series n. 65. UNESCO-IHE Institute for Water Education. Delft, The Netherlands.

Gasol, C.M., Gabarrell, X., Anton, A., Rigola, M., Carrasco, J., Ciria, P., Rieradevall, J., 2009. LCA of poplar bioenergy system compared with Brassica carinata energy crop and natural gas in regional scenario. Biomass and bioenergy 33, 119-129. http://doi.org/10.1016/j.biombioe.2008.04.020.

Ghanta, M., Fahey, D., Subramaniam, B., 2014. Environmental impacts of ethylene production from diverse feedstocks and energy sources. Applied petrochemical research, 4, 167-179. http://doi.org/10.1007/s13203-013-0029-7

Guinée, J.B., Gorrée, M., Heijungs, R., Huppes, G., Kleijn, R., van Oers, L. Sleeswijk A.W., Suh S., Udo de Haes H.A., de Bruijn H., van Duin R., Huijbregts M.A.J., 2001. Life Cycle Assessment: An Operational Guide to the ISO Standards. Parts 1, 2a \& 2b. Kluwer Academic Publishers, Dordrecht, The Netherlands.

Guo, M., Littlewood, J., Joyce, J., Murphy, R., 2014. The environmental profile of bio-ethanol produced from current and potential future poplar feedstocks in the EU. Green Chemistry 16, 4680-4695. https://doi.org/10.1039/C4GC01124D

Haro, P., Ollero, P., Villanueva Perales, A.L., Reyes Valle, C., 2012. Technoeconomic assessment of lignocellulosic ethanol production via DME (dimethyl ether) hydrocarbonylation. Energy 44(1), 891-901. https://doi.org/10.1016/i.energy.2012.05.004

Haro, P., Ollero, P., Trippe, F., 2013. Technoeconomic assessment of potential processes for bio-ethylene production. Fuel Processing Technology 114, 35-48. http://dx.doi.org/10.1016/i.fuproc.2013.03.024

Haro, P., Villanueva Perales, A.L., Arjona, R., Ollero, P., 2014. Thermochemical biorefineries with multiproduction using a platform chemical. Biofuels, Bioproducts and Biorefining 8(2), 155-170. http://dx.doi.org/10.1002/bbb.1409

Horváth, I.T., Cséfalvay, E., Mika, L.T., Debreczeni, M., 2017. Sustainability Metrics for Biomass-Based Carbon Chemicals. ACS Sustainable Chemistry \& Engineering 5(3), 2734-2740. https://doi.org/10.1021/acssuschemeng.6b03074

ICIS Pricing Data, 2014. Available at: www.icis.com

ISO, 2006a. ISO14040:2006 - Environmental Management - Life Cycle Assessment: Principles and Framework. International Standard Organization, Geneva, Switzerland.

ISO, 2006b. ISO14044:2006 - Environmental Management - Life Cycle Assessment: Requirements and Guidelines. International Standard Organization, Geneva, Switzerland.

JRC (Joint Research Centre), 2017. Emission Database for Global Atmospheric Research (EDGAR). Emissions time series, $\mathrm{CO}_{2}$ 1990-2015. Available at: http://edgar.jrc.ec.europa.eu/overview.php?v=CO2ts1990-2015

Kamzon, M.A., Abderafi, S., Bounahmidi, T., 2016. Promising bio-ethanol processes for developing a biorefinery in the Moroccan sugar industry. International Journal of Hydrogen Energy 41(45), 20880-20896. https://doi.org/10.1016/.j.jhydene.2016.07.035

Karka, P., Papadokonstantakis, S., Kokossis, A., 2017. Cradle-to-gate assessment of environmental impacts for a broad set of biomass-to-product process chains. The International Journal of Life Cycle assessment 22(9), 1418-1440. https://doi.org/10.1007/s11367-017-1262-6

Kikuchi, Y., Oshita, Y., Mayumi, K., \& Hirao, M., 2017. Greenhouse gas emissions and socioeconomic effects of biomass-derived products based on structural path and life cycle analyses: A case study of polyethylene and polypropylene in Japan. Journal of Cleaner Production, 167, 289-305. http://dx.doi.org/10.1016/j.jclepro.2017.08.179

Liptow, C., Tillman, A., Janssen, M., Wallberg, O., Taylor, G.A., 2013. Ethylene based on woody biomass - What are environmental key issues of a possible future Swedish production on industrial scale. The International Journal of Life Cycle assessment 18(5), 1071-1081. https://doi.org/10.1007/s11367-013-0564-6 
Liptow, C., Tillman, A.M., Janssen, M., 2015. Life cycle assessment of biomass-based ethylene production in Sweden - is gasification or fermentation the environmentally preferable route? The International Journal of Life Cycle Assessment. 20(5), 632-644.

McKechnie, J., Pourbafrani, M., Saville, B.A., MacLean, H.L., 2015. Environmental and financial implications of ethanol as a bioethylene feedstock versus as a transportation fuel. Environmental Research Letters 10, 124018. https://doi.org/10.1088/17489326/10/12/124018

Mitsubishi Chemical, 2017. Global Supply and Demand of Petrochemical Products relied on LPG as Feedstock. Mitsubishi Chemical Techno-Research.

Mohsenzadeh, A., Zamani, A., Taherzadeh, M.J., 2017. Bioethylene Production from Ethanol: A review and techno-economical evaluation. ChemBioEng Reviews 4(2), 75-91. https://doi.org/10.1002/cben.201600025

Moreno Ruiz, E., Lévová T., Reinhard J., Valsasina L., Bourgault G., Wernet G., 2016. Documentation of changes implemented in ecoinvent Data 3.3. Ecoinvent, Zurich, Switzerland.

NREL (National Renewable Energy Laboratory), 2006. Equipment Design and Cost Estimation for Small Modular Biomass Systems, Synthesis Gas Cleanup, and Oxygen Separation Equipment, Task 2.3: Sulfur Primer. Nexant Inc. San Francisco, California, USA.

Muñoz, I., Flury, K., Jungbluth, N., Rigarlsford, G., Mila i Canals, L., Kimg, H., 2014. Life cycle assessment of bio-based ethanol produced from different agricultural feedstocks. The international journal of life cycle assessment, 19(1), 109-119. http://doi.org/10.1007/s11367-013-0613-1

Nemecek, T., Schnetzer, J., 2012. Methods of assessment of direct field emissions for LCls of agricultural production systems (Data v3.0). Agroscope Reckenholz-Tänikon Research Station ART, Zurich, Switzerland.

Nitzsche, R., Budzinski, M., Gröngröft, A., 2016. Techno-economic assessment of a woodbased biorefinery concept for the production of polymer-grade ethylene, organosolv lignin $\begin{array}{llll}\text { and fuel. } \quad \text { Bioresource } & \text { 928-939. }\end{array}$ https://doi.org/10.1016/j.biortech.2015.11.008

Posen, I.D., Griffin, W.M., Matthews, H.S., Azevedo, I.L., 2015. Changing the renewable fuel standard to a renewable material standard: Bioethylene case study. Environmental Science \& Technology. 49(1), 93-102. https://doi.org/10.1021/es503521r

Pré Consultants B.V., 2017. SimaPro v.8.3. The Netherlands.

REE (Red Eléctrica Española), 2017. The electric system in Spain 2016 (in Spanish). Available in www.ree.es. Reyes Valle, C., Villanueva Perales, Vidal-Barrero, F., A.L., Ollero, P., 2015. Integrated economic and life cycle assessment of thermochemical production of bio-ethanol to reduce production cost by exploiting excess of greenhouse gas savings. Applied Energy 148, 466-475. http://dx.doi.org/10.1016/i.apenergy.2015.03.113

Sharifzadeh, M., Wang, L., Shah, N., 2015. Decarbonisation of olefin processes using biomass pyrolysis oil. Applied Energy 149, 404-414. https://doi.org/10.1016/j.apenergy.2015.03.081

Sutter, J., 2010. Life cycle inventories of pesticides (Data v2.2). Swiss Centre for Life Cycle Inventories, St. Gallen, Switzerland.

The Royal Society, 2016. The potential and limitations of using carbon dioxide. London.

Tsiropoulos, I., Faaij, A.P.C., Lundquist, L., Schenker, U., Briois, J.F., Patel, M.K., 2015. Life cycle impact assessment of bio-based plastics from sugarcane ethanol. Journal of Cleaner Production, 90, 114-127. http://dx.doi.org/10.1016/j.jclepro.2014.11.071

Villanueva, A.L., Reyes Valle, C., Ollero, P., Gómez Barea, A., 2011. Technoeconomic assessment of ethanol production via thermochemical conversion of biomass by entrained flow gasification. Energy 36(7), 4097-4108. http://dx.doi.org/doi:10.1016/i.energy.2011.04.037. 


\title{
Environmental assessment of thermo-chemical processes for bio-ethylene production in comparison with bio-chemical and fossil-based ethylene
}

\author{
Bernabé Alonso-Fariñas, Alejandro Gallego-Schmid, Pedro Haro, Adisa Azapagic
}

\section{Supporting information}

\section{Case 1: Direct ethanol dehydration}

Case 1 consists of three main steps:

i) bioslurry production from biomass;

ii) production of ethanol from bioslurry by direct route through gasification and catalytic conversion of the syngas; and

iii) production of ethylene by ethanol dehydration.

\section{i) Bioslurry production}

This section is show in Figure 2 in the paper. After it has been dried and grinded, the biomass is fed to a fast pyrolysis reactor in which it is converted into light gas, heavy hydrocarbons and biochar. The system is designed to be energy self-sufficient. A fraction of the biochar is burnt to supply the thermal energy required by the pyrolysis reactor. The light gas is purged and burned to produce electricity in a steam cycle. Flue gases from biochar and light gas combustion are used for drying. The bioslurry is composed of the remaining biochar and the bio-oil obtained from heavy hydrocarbon condensation. Due to the energy self-sufficiency, only $80 \%$ of the biomass energy is recovered in the bioslurry (Villanueva et al., 2011).

\section{ii) Production of ethanol from bioslurry}

The bioslurry is then fed to the gasifier ( $1300^{\circ} \mathrm{C}$ and 70 bar); see Figure 3 in the paper. The oxygen supplied to the gasifier is generated in a cryogenic air separation unit. The produced syngas is cooled and then cleaned up and conditioned before being fed to the synthesis loop. Particles (including alkalis) and $\mathrm{NH}_{3}$ (also possible traces of $\mathrm{NH}_{4} \mathrm{Cl}$ ) are removed with a candle filter and a Venturi scrubber, respectively. The $\mathrm{H}_{2} / \mathrm{CO}$ mole ratio is adjusted in a sour water-gas shift (WGS) reactor employing a sulphur-resistant Co-Mo catalyst. The synthesis loop comprises four stages: Selexol plant, synthesis reactor, autothermal reformer (ATR) and gas-liquid separator. The $\mathrm{CO}_{2}$ concentration is adjusted in the Selexol unit before feeding into the synthesis reactor. The sulphur contained in the acid gas from the Selexol process as $\mathrm{H}_{2} \mathrm{~S}$ is removed in a liquid-phase oxidation catalytic (LO-CAT) unit. The synthesis reactor utilizes a $\mathrm{MoS}_{2}$ catalyst for alcohols production. The effluent of the reactor is sequentially cooled, including a cryogenic stage, to separate the condensable products from the gas phase that comprises unreacted syngas and light products. This gas phase is sent to the ATR unit with steam and oxygen before recirculating. A ZnO bed is placed upstream of the ATR unit to remove all sulphur contained in the gas as it is a poison for the Ni reforming catalyst. The condensates from the gas-liquid separator are fed to a stabilizer where methanol $(>98 \% \mathrm{~mol})$ and dissolved gases are recovered. The water is completely removed in the dehydrator (zeolite molecular sieve). Finally, ethanol $(>98 \% \mathrm{~mol})$ and propanol $(>98 \%$ $\mathrm{mol}$ ) are separated by distillation. Therefore, methanol and propanol are generated as coproducts in this process. Dissolved gases recovered in the stabilizer and the purge from the synthesis loop (including unreacted syngas and light products) are sent to the combined cycle for power generation. Despite power generation in the combined cycle, this is not sufficient and additional electricity is imported from the grid.

\section{iii) Production of ethylene by ethanol dehydration}

Finally, the bioethanol is dehydrated to obtain ethylene (Figure 4 in the paper). The ethanol feedstock is mixed with water and preheated before entering the dehydration reactor train. The reaction train consists of a series of three adiabatic fixed-bed reactors filled with alumina catalyst (Cameron et al., 2012). Two gas-liquid separators, a dewatering unit (zeolite 
molecular sieve) and two fractionation columns, second one working with ammonia cryogenic system, are used to obtain ethylene $(>98 \% \mathrm{~mol})$. An external natural gas supply is required despite the energy recovered from the hydrocarbons in the fractionation columns and coke in the reactors.

\section{Case 2: Indirect ethanol dehydration}

This case involves two steps:

i) production of ethanol from biomass by indirect route; and

ii) production of ethylene by ethanol dehydration.

\section{i) Production of ethanol}

After drying and milling, the biomass is fed to an atmospheric indirectly-heated circulating fluidized bed gasifier (Figure 5 in the paper). Before being fed to the methanol synthesis loop, the syngas generated in the gasifier is cleaned up and conditioned. Particulates are partially collected in high-temperature cyclones. The rest of the particulates and tars are removed in the OLGA unit by scrubbing oil. Collected tars are recycled to the combustor of the gasifier. Nitrogenous compounds, alkalis and $\mathrm{HCl}$ are removed by scrubbing with water. $\mathrm{H}_{2} \mathrm{~S}$ is removed in the LO-CAT unit avoiding $\mathrm{CO}_{2}$ capture (needed for steam reforming). The concentration of $\mathrm{H}_{2} \mathrm{~S}$ is reduced to ppbv levels in a Co-Mo/ZnO catalyst dual bed (guard bed unit). The Co-Mo catalyst bed also hydrogenates olefins to paraffins which are easier to reform. Methane and light paraffins are converted into syngas in the steam methane reformer (SMR) using a Ni catalyst. A $\mathrm{CO}_{2}$ stream is recirculated into the SMR in order to get a $\mathrm{H}_{2} / \mathrm{CO}$ molar ratio equal to 1 at the inlet of the methanol synthesis reactor. Water is removed with a zeolite bed (dewatering unit) upstream of the synthesis loops.

A fraction of the syngas is sent to the hydrocarbonylation loop while the rest is transferred to the methanol synthesis reactor based on liquid-phase methanol (LPMEOH) technology with $\mathrm{Cu} / \mathrm{ZnO}$ catalyst. A gas-liquid separator is used for methanol recovery. The unreacted syngas stream from the gas-liquid separator is sent to the hydrocarbonylation synthesis reactor which is fed with three other streams: clean and conditioned syngas fraction from the SMR, recirculated unreacted syngas and dimethyl ether (DME), and a third stream that comprises DME from the methanol dehydration reactor and methyl acetate from the stabilizer column. An $\mathrm{H}$-mordenite catalyst is employed for ethanol production in the reactor. An amine scrubber using monoethanolamine (MEA) is used for $\mathrm{CO}_{2}$ capture to avoid a build-up of $\mathrm{CO}_{2}$ in the synthesis loop. Additionally, a purge is necessary in the hydrocarbonylation loop to prevent methane build-up. The condensate from the gas-liquid separator of the hydrocarbonylation loop is sent to a stabilizer column where alcohols are recovered. Methanol and ethanol are separated in a distillation column. Methanol is sent to the dehydration reactor to produce more DME and ethanol is obtained as a product.

The methanol synthesized in the LPMEOH reactor and co-produced in the hydrocarbonylation reactor are dehydrated to DME in a fixed-bed reactor using an alumina catalyst (Hosseini and Nikou, 2012). Water is removed from the DME stream in the DME column before being sent to the hydrocarbonylation reactor.

The process is energy self-sufficient owing to energy integration. The power demand of the plant is completely satisfied by diverting some cleaned-up syngas plus the purge and the light gases to a combined cycle gas turbine.

\section{ii) Production of ethylene}

The production of ethylene by dehydration of ethanol is the same as described in the previous section for Case 1. 


\section{Case 3: DME to olefins}

Case 3 comprises two main steps:

i) bioslurry production; and

ii) production of olefins.

\section{i) Bioslurry production}

The bioslurry production process is the same as described for Case 1.

\section{ii) Production of olefins}

Syngas production, cleaning up and conditioning are carried out as described for Case 1 . The synthesis section comprises two phases (Figure 6 in the paper). In the first reactor, DME is produced from syngas employing a $\mathrm{Cu} / \mathrm{ZnO}$ catalyst, CZA/HZSM-5 (Ogawa et al., 2003; Abu-Dahrieh et al., 2012). In the second reactor, olefins are produced from DME using a zeolite catalyst (Pérez-Uriarte et al., 2016). Between both reactors, fuel gas is recovered by distillation. The purification and separation train comprises water removal (two gas-liquid separator and zeolite molecular sieve), $\mathrm{CO}_{2}$ (Selexol unit and LO-CAT for sulphur removal), and fractionation columns (including cryogenic unit). Ethylene $(>98 \% \mathrm{~mol})$, propylene $(>98 \%$ mol) and liquefied petroleum gas (light gas and butenes) are obtained as co-products. Although the recovered fuel gas is sent to a combined cycle gas turbine for power generation, additional electricity is needed from the grid.

\section{Contribution analysis}

Table S1. Relative contribution of the categories in Table 2 (in the paper) for direct ethanol dehydration (Case 1), excluding the system credits $^{a}$

\begin{tabular}{lrrrrrrrrr}
\hline Impact $^{\mathrm{D}}$ & Biomass & Catalysts & $\begin{array}{c}\text { Bed } \\
\text { materials }\end{array}$ & Solvents & Water & Energy $^{\mathrm{C}}$ & $\begin{array}{c}\text { Emissions } \\
\text { to air }\end{array}$ & $\begin{array}{c}\text { Solid } \\
\text { waste to } \\
\text { landfill }\end{array}$ & $\begin{array}{c}\text { Wastewater } \\
\text { to } \\
\text { treatment }\end{array}$ \\
\hline ADPe & 3.2 & 93.4 & 1.6 & 0.1 & 0.0 & 1.7 & 0.0 & 0.0 & 0.0 \\
ADPf & 26.6 & 0.5 & 0.8 & 1.0 & 0.5 & 70.1 & 0.0 & 0.4 & 0.2 \\
GWP & 35.5 & 0.5 & 0.8 & 0.4 & 0.6 & 47.0 & 14.6 & 0.4 & 0.2 \\
ODP & 22.2 & 0.3 & 1.5 & 0.3 & 0.4 & 74.8 & 0.0 & 0.4 & 0.1 \\
HTP & 8.0 & 48.9 & 1.4 & 11.8 & 0.5 & 23.0 & 0.0 & 6.1 & 0.2 \\
FAETP & 22.4 & 37.2 & 2.0 & 0.1 & 0.7 & 15.6 & 0.0 & 21.8 & 0.3 \\
MAETP & 9.2 & 38.6 & 1.2 & 0.2 & 0.6 & 44.5 & 0.0 & 5.4 & 0.2 \\
TETP & 88.2 & 0.5 & 0.5 & 0.0 & 2.0 & 7.4 & 0.0 & 0.2 & 1.2 \\
POCP & 0.6 & 0.0 & 0.0 & 0.0 & 0.0 & 1.8 & 97.5 & 0.0 & 0.0 \\
AP & 35.6 & 1.3 & 0.9 & 0.4 & 1.2 & 51.3 & 8.3 & 0.4 & 0.6 \\
EP & 39.4 & 15.2 & 0.4 & 0.1 & 8.7 & 32.4 & 0.0 & 0.7 & 3.0
\end{tabular}

a The category "Other chemicals" shown in Table 2 in the paper has a negligible contribution and is not shown here.

${ }^{b}$ ADPe: abiotic depletion potential of elements. ADPf: abiotic depletion potential of fossil resources. GWP: global warming potential. ODP: ozone layer depletion potential. HTP: human toxicity potential. FAETP: freshwater aquatic ecotoxicity potential. MAETP: marine aquatic ecotoxicity potential. TETP: terrestrial ecotoxicity potential. POCP: photochemical oxidants creation potential. AP: acidification potential. EP: eutrophication potential).

${ }^{c}$ Excludes electricity consumption from the air separation unit as it is included in the energy balance of the ethylene production plant. 
Table S2. Relative contribution of the categories in Table 2 (in the paper) for indirect ethanol dehydration (Case 2), excluding the system credits $^{a}$

\begin{tabular}{lrrrrrrrrr}
\hline Impact $^{\mathrm{b}}$ & Biomass & Catalysts & $\begin{array}{c}\text { Bed } \\
\text { materials }\end{array}$ & Solvents & Water & Energy $^{\mathrm{c}}$ & $\begin{array}{c}\text { Emissions } \\
\text { to air }\end{array}$ & $\begin{array}{c}\text { Solid } \\
\text { waste to } \\
\text { landfill }\end{array}$ & $\begin{array}{c}\text { Wastewater } \\
\text { to } \\
\text { treatment }\end{array}$ \\
\hline ADPe & 13.9 & 77.5 & 3.9 & 0.2 & 1.1 & 3.2 & 0.0 & 0.0 & 0.1 \\
ADPf & 21.1 & 0.5 & 0.4 & 21.2 & 2.0 & 54.0 & 0.0 & 0.2 & 0.6 \\
GWP & 33.2 & 0.5 & 0.4 & 3.6 & 2.3 & 21.8 & 37.1 & 0.3 & 0.9 \\
ODP & 18.3 & 0.5 & 0.7 & 24.0 & 1.6 & 54.1 & 0.0 & 0.3 & 0.5 \\
HTP & 7.6 & 8.7 & 0.7 & 67.1 & 1.8 & 11.9 & 0.0 & 1.4 & 0.9 \\
FAETP & 38.2 & 13.0 & 1.9 & 1.2 & 4.0 & 14.2 & 0.0 & 25.3 & 2.1 \\
MAETP & 19.6 & 15.5 & 1.5 & 2.4 & 6.3 & 46.2 & 0.0 & 6.4 & 2.2 \\
TETP & 88.2 & 0.5 & 0.3 & 0.5 & 1.9 & 3.5 & 0.0 & 0.2 & 5.0 \\
POCP & 27.2 & 4.9 & 0.8 & 11.1 & 3.7 & 47.6 & 1.7 & 0.6 & 2.3 \\
AP & 46.8 & 4.3 & 0.7 & 6.4 & 3.4 & 35.2 & 0.0 & 0.4 & 2.9 \\
EP & 36.0 & 2.5 & 0.2 & 1.5 & 34.8 & 13.1 & 0.0 & 0.7 & 11.3
\end{tabular}

${ }^{\text {a }}$ The category "Other chemicals" shown in Table 2 in the paper has a negligible contribution and is not shown here.

${ }^{\mathrm{b}}$ For the acronyms. see Table S1.

${ }^{c}$ Excludes electricity consumption from the air separation unit as it is included in the energy balance of the ethylene production plant.

Table S3. Relative contribution of the categories in Table 2 (in the paper) for DME to olefins (Case 3), excluding the system credits $^{a}$

\begin{tabular}{lrrrrrrrrr}
\hline Impact $^{\mathrm{D}}$ & Biomass & Catalysts & $\begin{array}{c}\text { Bed } \\
\text { materials }\end{array}$ & Solvents & Water & Energy $^{\mathrm{C}}$ & $\begin{array}{c}\text { Emissions } \\
\text { to air }\end{array}$ & $\begin{array}{c}\text { Solid } \\
\text { waste to } \\
\text { landfill }\end{array}$ & $\begin{array}{c}\text { Wastewater } \\
\text { to } \\
\text { treatment }\end{array}$ \\
\hline ADPe & 1.7 & 96.9 & 0.0 & 0.0 & 0.0 & 1.4 & 0.0 & 0.0 & 0.0 \\
ADPf & 26.6 & 5.0 & 0.0 & 0.7 & 0.2 & 66.7 & 0.0 & 0.6 & 0.2 \\
GWP & 32.4 & 4.2 & 0.0 & 0.3 & 0.2 & 62.1 & 0.0 & 0.6 & 0.2 \\
ODP & 19.3 & 10.0 & 0.0 & 0.2 & 0.1 & 69.9 & 0.0 & 0.5 & 0.1 \\
HTP & 6.1 & 57.5 & 0.0 & 5.9 & 0.1 & 25.3 & 0.0 & 5.0 & 0.2 \\
FAETP & 19.9 & 39.5 & 0.0 & 0.1 & 0.2 & 20.1 & 0.0 & 20.0 & 0.2 \\
MAETP & 7.2 & 34.5 & 0.0 & 0.1 & 0.2 & 53.2 & 0.0 & 4.5 & 0.2 \\
TETP & 81.5 & 6.4 & 0.0 & 0.0 & 0.4 & 10.5 & 0.0 & 0.3 & 1.0 \\
POCP & 1.5 & 1.2 & 0.0 & 0.0 & 0.0 & 6.0 & 91.1 & 0.1 & 0.0 \\
AP & 27.1 & 11.5 & 0.0 & 0.2 & 0.2 & 55.1 & 4.8 & 0.5 & 0.4 \\
EP & 34.2 & 15.1 & 0.0 & 0.1 & 3.8 & 43.6 & 0.0 & 0.8 & 2.5
\end{tabular}

a The category "Other chemicals" shown in Table 2 in the paper has a negligible contribution and is not shown here.

${ }^{\mathrm{b}}$ For the acronyms. see Table S1.

${ }^{c}$ Excludes electricity consumption from the air separation unit as it is included in the energy balance of the ethylene production plant.

\section{References}

Abu-Dahrieh. J.. Rooney. D.. Goguet. A.. Saih. Y.. 2012. Activity and deactivation studies for direct dimethyl ether synthesis using $\mathrm{CuO}-\mathrm{ZnO}-\mathrm{Al} 2 \mathrm{O} 3$ with $\mathrm{NH}(4) \mathrm{ZSM}-5$. HZSM-5 or gamma-Al2O3. Chemical Engineering Journal 203. 201-211.

Cameron. G.. Le. L.. Levine. J.. Nagulapalli. N.. 2012. Process Design for the Production of Ethylene from Ethanol. Senior Design Reports (CBE). Paper 39. http://repository.upenn.edu/cbe sdr/39.

Hosseini. Y.S. and Nikou. M.R.K.. 2012. Modeling of Industrial Fixed Bed Reactor to Produce Dimethyl Ether from Methanol and Determination of Optimum Operating Conditions. Journal of American Science 8(5). 218-225.

Ogawa. T.. Inoue. N.. Shikada. T.. Ohno. Y.. 2003. Direct Dimethyl Ether Synthesis. Journal of Natural Gas Chemistry 12(4). 219-227.

Pérez-Uriarte. P.. Ateka. A.. Aguayo. A.T.. Gayubo. A.G.. Bilbao. J.. 2016. Kinetic model for the reaction of DME to olefins over a HZSM-5 zeolite catalyst. Chemical Engineering Journal 302. 801-810.

Villanueva. A.L.. Reyes Valle. C.. Ollero. P.. Gomez Barea. A.. 2011. Technoeconomic Assessment of ethanol production via thermochemical conversion of biomass by entrained flow gasification. Energy 36(7). 40974108. 